\title{
Demand for and Adequacy of International Reserves in Sri Lanka
}

\author{
Dimuthu Samaratunga and Anil Perera ${ }^{1}$
}

\begin{abstract}
During the last few decades, especially emerging economies have opted to accumulate large stocks of international reserves to withstand unexpected external turbulences and also to reinforce external sector performances through maintaining exchange rate stability. Substantial reserve accumulation entails several benefits as well as direct and indirect costs. Particularly, holding excess reserves for a long time could generate welfare losses which is an important policy consideration. In this context, the key objectives of our study are twofold: first to develop a reserve demand model based on historical data; and second, to assess the reserve adequacy for Sri Lanka based on conventional and recent methodological innovations in the reserve adequacy literature. Based on data for the period 1996 - 2012, we observe that international reserves in Sri Lanka are broadly determined by import propensity, trade openness, short-term debt and liabilities and money supply. In terms of key conventional measures of reserve adequacy, we find that Sri Lanka has held adequate reserves, despite some variations in some years. At the same time, based on the new risk-weighted reserve adequacy metrics proposed by the International Monetary Fund, we observe that Sri Lanka has had adequate levels of reserves except in the years 2000, 2008 and 2011.
\end{abstract}

1 We are grateful to Dr. Nandalal Weerasinghe, Mrs. Swarna Gunaratne and Dr. D.S. Wijesinghe for encouraging us and providing valuable comments and suggestions. We also thank Mr. H.P.G.S. Ratnasiri, Ms. Erandi Liyanage and Ms. Kaushalya Subasinghe for their support. We are responsible for any remaining errors in the paper.

Correspondence: Dimuthu Samaratunga - dimuthu@cbsl.lk; dimuthu.samaratunga@gmail.com Anil Perera - anilraa@cbsl.lk; anil.perera@monash.edu; anilraa@yahoo.com. 
This new metrics appears to be a better standard to measure reserve adequacy than the conventional bench-marks from a precautionary perspective. Our results have important policy implications for exchange rate, reserve accumulation and the monetary policy of the Central Bank of Sri Lanka.

JEL Classification: F31, F32, F41

Key Words: International Reserves, Reserve Adequacy, Reserves

Demand Function, Risk-Weighted Reserve Adequacy

Metrics

\section{PART 1: INTRODUCTION}

An individual country's international reserves consist of the stock of assets held by its central bank (or monetary authority) that can be converted, with certainty, into another financial medium and used to influence the value of the country's exchange rate. International reserves (also called foreign exchange reserves) are generally defined in gross terms in the literature, to include central bank holdings of convertible foreign exchange, gold, special drawing rights (SDRs) and the reserve position at the International Monetary Fund (IMF) (Bahmani-Oskooee and Brown, 2002). In a technical sense, the IMF defines an economy's international reserves as "those external assets that are readily available to and are controlled by monetary authorities, for direct financing of payment imbalances through intervention in exchange markets, to affect currency exchange, and/or for other purposes (IMF Balance of Payments Manual, 1993).

Foreign reserves are demanded by countries with a view to build a buffer against sudden withdrawal of foreign exchange or to manage exchange rates to support the export sector. Hence, international reserves provide two main benefits: self-insurance against financial turbulence and mercantilist export promotion. However, during recent decades, reserve accumulation has become subservient in industrial countries. Particularly, over the past three decades, shifts to flexible exchange rate regimes and the ability to borrow in domestic currency have eased pressure on industrial countries to accumulate reserves (Green and Torgerson, 2007). In contrast, emerging countries have been pursuing sustainable efforts to build-up large stocks of international reserves. ${ }^{2}$

2 International reserves in emerging economies are four times as large as in the early 1990s in terms of their GDP (Jeanne, 2007). 
Amongst emerging economies, several Asian economies have accumulated large stocks of international reserves (García and Soto, 2004). The 1997 crisis in East Asia led to profound changes in the demand for international reserves and hence motivated Asian countries to aggressively hoard reserves over time (Aizenman and Lee, 2007; Ruiz-Arranz Zavadjil 2008; Cheung and Ito, 2009). In particular, some Asian countries like China, Japan, Korea, Malaysia, and Taiwan have attempted to accumulate large amounts of reserves, fuelling the recent discussion/debate of the extraordinary and puzzling accumulation of international reserves in the new millennium (Cheung and Qian, 2009). Table 1 shows reserve levels of selected countries including the top ten reserve holders by 2011. It appears that Asian countries dominate reserve accumulation and it is also observed that substantial reserve accumulation was driven by both precautionary and mercantilist motives (Park and Estrada, 2009).

Table 1

Ranking of Countries by Foreign Exchange Reserves (at end 2011)

\begin{tabular}{rlrr}
\hline Rank & \multicolumn{1}{c}{ Country } & $\begin{array}{r}\text { Foreign Exchange Reserves } \\
\text { (USD Mn) }\end{array}$ & $\begin{array}{c}\text { Share } \\
(\mathbf{\%})\end{array}$ \\
\hline 1 & People's Republic of China & $3,204,610$ & 29.9 \\
2 & Japan & $1,259,494$ & 11.8 \\
& Eurosystem $^{1 /}$ & 932,675 & 8.7 \\
3 & Saudi Arabia & 541,234 & 5.1 \\
4 & Russia & 455,474 & 4.3 \\
& Republic of China (Taiwan) & 386,277 & 3.6 \\
5 & Brazil & 350,414 & 3.3 \\
6 & Republic of Korea & 304,349 & 2.8 \\
& Hong Kong & 285,300 & 2.7 \\
7 & Switzerland & 281,187 & 2.6 \\
8 & India & 272,249 & 2.5 \\
9 & Germany & 256,455 & 2.4 \\
10 & Singapore & 255,769 & 2.4 \\
\hline 17 & United States & 150,964 & 1.41 \\
19 & United Kingdom & 79,808 & 0.75 \\
37 & Australia & 42,921 & 0.40 \\
57 & Pakistan & 14,639 & 0.14 \\
65 & Bangladesh & 8,533 & 0.08 \\
69 & Sri Lanka & 6,000 & 0.06 \\
\hline
\end{tabular}

Source: IMF, International Financial Statistics (IFS)

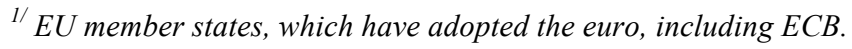


With the build-up of substantial reserves positions, particularly in Asian countries, there had been a growing consensus that the reserve levels of many Asian countries now far exceed all plausible estimates of what they need for liquidity purposes, or in other words, the reserve levels are substantially above optimal levels (Park and Estrada, 2009). Hence, particularly during the last decade, there is a growing interest of empirical research on the different aspects of international reserves such as the optimal level, adequacy, demand and determinants, cost and benefits, and management of international reserves.

In Sri Lanka, both key motives of reserves accumulation have been important. During the recent episodes of financial crisis, Sri Lanka's international reserves declined substantially to low levels mainly due to the impact of significant outflows of short term foreign investments and the drain of foreign exchange inflows on account of the dampened external environment. Several measures taken by authorities helped to boost foreign exchange inflows received by Sri Lanka, advancing the reserve position to historically high levels. Foreign exchange reserves reaching higher levels induce interest for investors, policy makers and particularly researchers. This is due to benefits such as protection against unexpected shortages of foreign exchange and currency crisis and also the costs such as opportunity and welfare losses associated with the accumulation of large and excessive amounts of foreign reserves. These concerns are particularly important in the Sri Lankan context, given the record high levels of international reserves in recent years and hence Sri Lanka is a particularly interesting country to examine the demand and adequacy of international reserves, contributing to the ongoing discussion in this area. To that end, the objectives of our study are to develop a reserve demand model for Sri Lanka and to assess the level of reserve adequacy of the country in terms of conventional as well as the risk-weighted metrics proposed by the IMF. As far as we are aware, this is the first attempt to conduct an empirical study on the country's international reserves. ${ }^{3}$ The findings of our study would be useful for policy makers in general, in better calibrating macroeconomic policies in Sri Lanka and also to the Central Bank of Sri Lanka (CBSL) in particular, in pursuing its exchange rate and reserve management policies.

The remainder of this paper is structured as follows: Part 2 of the paper contains a discussion of the conceptual outline of international reserves including different measures of reserve adequacy and a review of prior academic literature. Part 3 provides the analysis and the related discussion pertaining to demand and adequacy of international reserves in Sri Lanka, followed by the conclusion.

3 Sri Lankan context is considered in prior literature, for example, Hauner, 2006; Cheung and Qian, 2009 and Dominguez, Hashimoto and Ito, 2012, only as part of a large panel of countries and do not focus on individual country-specific discussion. 


\section{PART 2: CONCEPTUAL OUTLINE}

In this section, we attempt to provide a comprehensive discussion of the motivations, determinants and costs and benefits associated with international reserves and review prior theoretical and empirical literature.

\subsection{Motivations for Reserve Accumulation}

The traditional purposes for holding international reserves have been to: directly finance international payments imbalances; intervene in financial markets to provide liquidity in times of crisis; and influence the exchange rate (Neely, 2000). It clearly indicates that traditionally, the reserves accumulation motive was centered around exchange rate considerations. As such, during the 1960s, the debate focused on defining the optimal level of international reserves necessary to maintain the value of a currency, within the fixed exchange rate systems (García and Soto, 2004). Particularly, when countries opt to maintain a certain level of stability in the exchange rates, they would need to hold adequate levels of international reserves. Therefore, foreign reserve accumulation becomes a prime motive of the monetary authority in countries focusing predominantly on exchange rate stability.

Based on the contemporary practices of reserve accumulation across countries, Cruz and Walters (2008) define three main motives behind reserve accumulation: (i) precaution, (ii) mercantilist approach and (iii) policy autonomy.

First, theoretically, large precautionary demand for international reserves arises as a self-insurance to avoid costly liquidation of long-term projects when the economy is susceptible to sudden stops of capital flows (Aizenman and Lee, 2007). During the 1970s, when most countries adopted free floating foreign exchange rate regimes, international reserves were seen as a buffer to absorb a transitory current account shock (García and Soto, 2004). Particularly, the issue of the accumulation of international reserves has regained relevance since the mid-1990s because of the occurrence of financial crises in the developing world, which were associated with the adoption of the neo-liberal liberalization strategy of free mobility of capital, notably in Mexico, Thailand, Korea, Malaysia, Philippines, Indonesia, Brazil, Turkey, Russia and Argentina (Aizenman and Lee, 2007). Hence, stockpiling international reserves has been seen as the central policy option that a country can pursue to avoid a financial crisis and its high economic costs (Bird and Rajan, 2003). 
Second, the mercantilist view focuses on hoarding international reserves in order to maintain a competitive real exchange rate with the ultimate goal of increasing export growth (Wijnhold and Kapteyn, 2001, Aizenman and Lee, 2007). Frenkel and Ros (2006) argue that if the rate of accumulation in the tradable goods sector is a positive function of profitability, and profitability in that sector is a positive function of the RER, then a competitive RER will lead to faster growth of the traded goods sector. In this sense, a more depreciated currency is equivalent to a uniform tariff on imports. Thus, by maintaining a competitive RER with the concomitant reserve accumulation, the profitability of the tradable sector can be promoted and, in turn, firms will invest and expand production. ${ }^{4}$ Reserve accumulation is also used as a policy tool for growth (Noyer, 2007). Dooley, Garber, and Folkerts-Landau (2003) argue that Asian emerging economies are pursuing export-led growth strategies by deliberately maintaining undervalued exchange rates, while providing the funding for the US current account deficit, as the US is a key consumer of these exports. Further, central banks in dollarized financial systems may need foreign exchange reserves to serve as a lender of last resort to banks with high levels of foreign currency liabilities (Green and Torgerson, 2007).

Third, the policy autonomy argument contends with multilateral institutional attachments of countries. Avoiding financial crises avoids the interference of and dependence on international agencies. The eruption of financial crises has led to the involvement of international multilateral institutions, and their conditional assistance packages, with an inevitable loss of policy autonomy. If countries attempt to prevent a crisis through the accumulation of liquidity, they could also minimise conditional assistance from multilateral agencies and gain policy autonomy, even in the event of a crisis actually occurring. Therefore, developing countries see reserve accumulation as a strategy of policy independence or sovereignty (Cruz and Walters, 2008). ${ }^{5}$

4 Aizenman and Lee (2007) find that variables associated with trade openness and exposure to financial crises are both statistically and economically important in explaining reserves. In contrast, variables associated with mercantilist concerns are statistically significant, but economically insignificant in accounting for the patterns of hoarding reserves. They also provide a model that shows that precautionary demand is consistent with high levels of reserves.

5 As external vulnerability is high in those countries, the pattern in reserve demand also significantly differs from developed countries (Wijnhold and Kapteyn, 2001). Hence, in summary, the precautionary, mercantilist and policy sovereignty motives are the driving forces behind developing countries' hoarding of international reserves (Cruz and Walters, 2008). 


\subsection{Determinants of International Reserves}

In many past empirical studies, some key variables have been found to be robust predictors of a country's holdings of international reserves. Such variables include: the current account balance, exchange rate regime, and marginal propensity to import (Romero, 2005). The most recent extended literature identifies a range of variables that may influence reserve holdings. Since there is no consensus on a theoretical model of reserves behaviour, these take a broad approach and attempt to include a large number of potential determinants such as output per capita, trade openness, country size, export volatility, financial development, capital controls, the exchange rate regime, an oil dummy, and external debt variables (Lane and Burke, 2001).

According to the literature, determinants of international reserves can be divided into three categories: traditional macro variables, financial variables, and institutional variables. The group of traditional macro variables consists of the propensity to import, volatility of real export receipts, international reserve volatility, the opportunity cost of holding international reserves, real per capita Gross Domestic Product (GDP), and population. These variables have been commonly considered as macro determinants since the 1960s. The second group of explanatory variables includes money supply, external debt, and capital flows. The use of money in explaining the hoarding of international reserves can be dated back to the 1950s. The third group of explanatory variables is institutional variables. It has been argued that institutional characteristics like corruption, political stability, and capital controls affect the hoarding of international reserves (Cheung and Ito, 2009).

The IMF (2003) categorises the determinants of reserve holdings into five categories, namely economic size, current account vulnerability, capital account vulnerability, exchange rate flexibility and opportunity cost. This approach of categorisation is used throughout the current study.

\subsection{Benefits and Costs of Reserve Accumulation}

Maintaining a high level of international reserves can help an economy, particularly a small open economy, to smooth-out the domestic impact against external shocks and hence reduce the welfare cost of a crisis. As argued by Jeanne (2007), there are two ways in which reserves can help to mitigate the impact of a balance of payments crisis on domestic welfare. First, the reserves can be used to mitigate the fall in domestic output. Second, the reserves can be used to buffer the impact of the balance of payments shock on domestic absorption. 
Furthermore, it is argued that reserves help to maintain stability in exchange rates and hence, to promote export growth through a competitive RER. In some cases, although exchange rate stability is not explicitly focused, large stocks of reserves may reduce the volatility in the exchange rate by way of reducing speculative attacks (Aizenman, 2006; Aizenman and Riera-Critchton, 2006; Cady and Gonzalez-Garcia, 2006). In addition, as a result of large reserves, the cost of foreign borrowing may also be reduced (Cruz and Walters, 2008).

However, many agree that holding reserves, particularly holding excess reserves, incurs costs than benefits (Park and Estrada, 2009). The prime cost of international reserves is usually defined as the opportunity cost of not consuming them, or not investing them in a more profitable manner. Reserves could be spent on the consumption of imported goods rather than being accumulated in the central bank. Hence, reserve accumulation leads to a welfare cost of postponing the consumption of tradable goods. ${ }^{6}$

Reserve accumulation could lead to some monetary costs to the monetary authority and fiscal costs to the government. When monetary authorities acquire international reserves, they typically require sterilising the effect of the foreign currency purchases on the domestic monetary base, which would lead to incurring domesticcurrency liabilities. At the same time, reserves held by the fiscal authority are typically financed with domestic government bills. If the interest rate on reserve assets is lower than the domestic interest rate, holding reserves entails quasi-fiscal costs (Dominguez et al., 2012). Moreover, reserves have a fiscal (opportunity) cost as they could alternatively be used to finance public investment or to pay down external debt and reduce interest expenditure. Hence, it is considered that reserves can have a substantial fiscal impact through interest expenditure, central bank profits and - indirectly - a lack of funds for public investment (Hauner, 2006). Furthermore, holding reserves also exposes the country to currency risk. If the domestic currency appreciates against the currencies denominating the reserve assets, the domestic currency value of reserves drops (Dominguez et al., 2012).

Mohanty and Turner (2006) show that large and prolonged reserve accumulation aimed at resisting or delaying currency appreciation can create a range of domestic macroeconomic risks through its effects on the balance sheets of the central bank and the

6 This cost can be proxied by the difference between the interest rate at which domestic consumers would be ready to borrow in order to increase their consumption of tradables and the rate of return on reserves (Jeans, 2007). 
private sector including near-term inflation, ineffective sterilisation, high intervention costs and monetary imbalances. Park and Estrada (2009) observe three major costs of reserve accumulation: inflation, fiscal costs, and higher interest rates. In addition to the aforementioned direct costs, reserve accumulation can be counterproductive, potentially generating further long term imbalances (Cruz and Walters, 2008). For example, large reserve stocks may create moral hazard problems that could weaken the financial system of a country, causing crises to be deeper, as currency intervention injects liquidity into domestic money markets, producing liquid market systems that can spill over into overheated asset markets and perhaps distort the banking system (Schiller, 2007).

In addition, the empirical significance of using international reserves to promote growth (the mercantilist view) is contested (Cruz and Walters, 2008). ${ }^{7}$ Reserve hoarding may exacerbate trade competition and emphasize regional tensions rather than promoting export growth.

\subsection{Assessing Reserve Adequacy}

Wijnhold and Kapteyn (2001) observe three major developments during the last fifty years with regard to reserve adequacy. First, the focus on money based measures, which was prevalent prior to the Bretton Wood System, has been largely diverted. Second, during the post-World War II period, reserve adequacy in individual countries has been entirely defined in terms of trade and trade variability. Third, the focus on different levels of development and market access between countries and different types of exchange rate regimes have been increased in explaining different levels of demand for reserves. Although trade based measures of reserve adequacy have gained much importance for a long period of time, contemporary analysis of reserve adequacy focuses on broader measures. Accordingly, four major reserve adequacy ratios can be found in contemporary literature: reserves to short-term external debt, reserves to broad money, months of imports and reserves to GDP. Ratios of reserves to short-term external debt and broad money are measures of reserve adequacy pertaining to reducing an economy's vulnerability to capital account shocks (Park and Estrada, 2009). At the same time, it is also observed that reserve adequacy measures essentially are influenced by the internal and external drain of financial assets during crises. Hence, broad money and short-term debt based indicators and/or the combination of these two ratios become the significant determinants of international reserve adequacy, particularly for emerging economies

7 During the last decade, developing (and some developed) economies have accumulated large amounts of international reserves, mainly for precautionary reasons. However, according to Cruz and Kriesler (2008), this phenomenon has been coupled with moderate economic growth. 
(Ozyildirim and Yaman, 2005). These four conventional measures are briefly explained below:

\section{(i) Import Coverage}

Until recently, the most widely spread indicator of reserve adequacy was reserves expressed in months of imports of goods and services. To that end, contemporary literature considers the reserve-to-import ratio, a proper measure of reserve adequacy and a three month prospective level of imports cover became the rule of thumb to determine the adequacy (Fischer, 2001). This criterion which implies forward import covered by reserves, is a guarantee of no hindrance in external trade transactions even in a case of complete cut off from foreign flows (Sehgal and Sharma, 2008). Although, such three month benchmark was earlier considered sufficient for adjusting imports without shocks to the economy, financial crises proved this indicator itself is insufficient to avoid problems and it should be augmented with additional criteria (Shcherbakov, 2002).

\section{(ii) Reserves to Short-term External Debt and Liabilities}

The ratio of reserves to short-term external debt and liabilities indicates that reserves should allow a country to sustain without foreign borrowing for up to one year (Jeanne, 2007). More precisely, according to the Greenspan-Guidotti rule, ${ }^{8}$ the critical value of this ratio is one (or $100 \%$ ), with a value above one signalling safety and a value below one signalling adverse implications. Hence, a country with reserves equal to or more than all external debt falling within one year, should be able to service its immediate external obligations even during a financial crisis. This ratio appears to be the most relevant single indicator of reserves for countries that borrow in international financial markets (Wijnhold and Kapteyn, 2001) and serves as a significant determinant of an economy's vulnerability to financial crisis (Park and Estrada, 2009).

\section{(iii) Reserves to Broad Money}

The ratio of reserves to broad money (more specifically $\mathrm{M}_{2}$ ) is especially relevant for countries at a significant risk of capital flight. Hence, this ratio indicates the degree of risk of capital flight from the country (Chan, 2007). Also, this is considered a decent indicator of reserve adequacy where demand of money supply is not stable and financial markets are not strong (Sehgal and Sharma, 2008). The basic premise is that the higher the ratio, the greater the confidence of the general public in the value of the local

8 The "Greenspan-Guidotti" rule recommends that reserves should enable full coverage of total short-term external debt in order to be able to pay back that debt in the event of a sudden termination of the rolling-over of foreign debt (Noyer, 2007). 
currency and hence lower the likelihood of massive crisis-provoking flights into other currencies. There is no general consensus on the critical value of the reserves to $\mathrm{M}_{2}$ ratio, given the inherent difficulty of measuring capital flight. However, Wijnholds and Kapteyn (2001), suggest reserves equivalent to $5-20 \%$ of $\mathrm{M}_{2}$ (depending on the exchange rate regime) is an acceptable level for this ratio.

\section{(iv) Reserves to GDP}

In the reserve adequacy literature, for example, Aizenman and Lee (2007), Lloyd-Ellis and Nechi (2008) and Park and Estrada (2009), among others, the ratio between international reserves and GDP is taken as an indicator for reserve adequacy. Reserves equal to $10 \%$ of GDP is considered the benchmark. It is argued that self-insurance against external liquidity problems cannot be simply explained by the reserves to GDP ratio (Lloyd-Ellis and Nechi, 2008). Although comparing a large amount of GDP with a small amount of reserve does not provide a reasonable basis, it still provides some implication about such large economy's need of reserves for dealing with larger amounts of international capital flows and trade.

Although these measures are informal rules of thumb, based on general economic intuition rather than rigorously derived theoretical concepts and models, they provide useful guidance for policymakers. In particular, many such studies find the ratio of reserves to short-term external debt to be a significant determinant of an economy's vulnerability to financial crisis (Park and Estrada, 2009). However, considering the advantages and disadvantages of these indicators, it is suggested they should be used simultaneously (Calvo and Mendoza, 1996, Berg and Pattillo, 1999).

Recently, the IMF has developed a new methodology to assess the reserve adequacy across countries based on a risk-weighted approach. It is being argued that conventional approaches of assessing reserve adequacy do not appear to be fairly representative and therefore not closely followed by countries in their reserve-holding decisions (IMF, 2011). As such, the IMF suggests a new metrics to encompass various possible drains on reserves. This appears to perform well as a more broad-based measure against which to assess reserves levels. We discuss this measure in detail in Part 3.

\subsection{Theoretical and Empirical Literature}

As Park and Estrada (2009) observe, theoretical and empirical literature exploring reserve adequacy more rigorously was very limited until very recently. However, there has been 
increased motivation for theoretical and empirical research on optimal reserves with the surge in reserves in emerging countries, particularly in Asia.

Many researchers have focused on constructing theoretical models, which can be used to analyse the reserve demand and adequacy under different circumstances. For example, Özdemir (2004), Jeanne and Rancière (2006), Barnichon (2008), Drummond and Dhasmana (2008), Li, Sula and Willett (2008), Dehesa, Pineda and Samuel (2009), Tereanu (2010), among others have developed theoretical models to assess the optimal level of reserves under different conditions and parameters affecting the reserve endowment. To that end, these theoretical underpinnings incorporate macroeconomic factors, such as monetarism, as well as microeconomic central bank optimizing behaviour (Bahmani-Oskooee and Brown, 2002).

At the same time, a number of empirical studies discuss demand and adequacy of international reserves. The empirical literature can be divided into two distinct periods, i.e., pre-1973 literature when most countries participated in the Bretton-Woods Agreement of fixed exchange rates and post-1973 which coincided with the newly instituted floating-rate system (Bahmani-Oskooee and Brown, 2002). The empirical interest is significant and useful during this floating-rate system and we discuss some empirical attempts in the context of our study.

For example, Aizenman and Marion (2003) measure reserve demand in a broad cross-section of countries, compare predicted to observed reserves outside the sample period and then find evidence for excess reserve accumulation. Also, Edison (2003) estimates a demand model using panel data for 122 emerging countries for the period 1980-1996 and finds that while actual reserves were broadly in line with forecasts during 1997-2001, actual reserves exceeded forecasts after 2001. Meanwhile, Aizenman, Lee and Rhee (2004) characterise the precautionary demand and show that the crisis led to structural change in the hoarding of international reserves in Korea. Mendoza (2004) investigates a possible self-insurance motivation behind increased reserve-holding in the developing world after the Asian financial crisis and proves that several countries accumulate reserves with the self-insuring motive. Gosselin and Parent (2005) estimate a long-run reserve-demand function for a panel of eight Asian emerging-market economies, find evidence for a positive structural break in the demand for reserves in the aftermath of the financial crisis of 1997-98, and indicate that the actual level of reserves was in excess relative to that predicted by the model. Using panel data from 21 African countries, Elhiraika and Ndikumana (2007) show that reserve accumulation cannot be justified by portfolio choice motives or stabilization objectives. Moreover, Marta and Zavadjil (2008) empirically suggest that reserves are not too high in the majority of Asian 
countries, though China may be a special case and conclude that much of the reserve increase in Asia can be explained by an optimal insurance model under which reserves provide a steady source of liquidity to cushion the impact of a sudden stop in capital inflows on output and consumption. Sehgal and Sharma (2008) analyse the demand function of India's reserve holdings and find evidence for both precautionary as well as mercantile motive behind holding excess reserves. Park and Estrada (2009) re-estimate the same model of Edison (2003) using panel data for 130 emerging economies from 1980 to 2004. The coefficients of their model have the expected signs and hence, estimation results are broadly similar with those of Edison.

\section{PART 3: DEMAND FOR AND ADEQUACY OF INTERNATIONAL RESERVES IN SRI LANKA}

In this section, we briefly discuss developments in international reserves in Sri Lanka and then develop a reserve demand model followed by an estimation of reserve adequacy based on the new risk-weighted metrics.

\subsection{Trends in International Reserves in Sri Lanka}

The Sri Lankan economy has experienced several external shocks since independence. Although the Sri Lankan economy benefitted from a few export booms (eg. during the Korean War in the 1950s), it was frequently affected by sharp downturns in exports, particularly during 1957-60 and 2008-2009 and the sharp increase in imports due to escalation of oil prices in 1973-74, 1981 and 2007-2008 (CBSL Annual Reports, 1998-2009). Such declines in terms of trade led to sharp contractions in gross official reserves $(\mathrm{GOR})^{9}$ to critical levels during several periods. The performance in the external sector during the last sixty years is illustrated in Table 2.

9 Gross official reserves (GOR), excluding the Asian Clearing Union (ACU) balances, have been considered throughout this paper. 
Table 2

Selected External Sector Indicators by Decades (1951 - 2010)

Period Averages

\begin{tabular}{|c|c|c|c|c|c|c|}
\hline Indicator & $\begin{array}{c}1951- \\
1960\end{array}$ & $\begin{array}{c}1961- \\
1970\end{array}$ & $\begin{array}{c}1971- \\
1980\end{array}$ & $\begin{array}{c}1981- \\
1990\end{array}$ & $\begin{array}{c}1991- \\
2000\end{array}$ & $\begin{array}{c}2001- \\
2010\end{array}$ \\
\hline Export Growth (\%) & 3.3 & -0.9 & 13.0 & 7.4 & 11.1 & 3.3 \\
\hline Import Growth (\%) & 6.1 & -0.5 & 20.6 & 3.0 & 10.8 & 5.2 \\
\hline $\begin{array}{l}\text { Current Account Balance } \\
(\% \text { of GDP) }\end{array}$ & -1.0 & -2.7 & -3.4 & -6.6 & -0.5 & -3.2 \\
\hline $\begin{array}{l}\text { Debt Service Ratio } \\
\text { (\% of earnings from } \\
\text { exports of goods and } \\
\text { services) }\end{array}$ & 1.7 & 4.7 & 19.2 & 21.4 & 15.5 & 13.2 \\
\hline $\begin{array}{l}\text { Exchange Rate } \\
\text { (US dollar/LKR) }\end{array}$ & 4.8 & 5.0 & 8.6 & 25.8 & 52.3 & 99.7 \\
\hline $\begin{array}{l}\text { Gross Official Reserves } \\
\text { (USD Mn) }\end{array}$ & 170 & 65 & 186 & 366 & 1,544 & 2,812 \\
\hline $\begin{array}{l}\text { Months of Imports } \\
\text { (Same Year's Imports) }\end{array}$ & 6.0 & 1.9 & 2.5 & 2.1 & 3.7 & 3.5 \\
\hline
\end{tabular}

Sources: CBSL, IFS

Figure 1 illustrates the historical movements of Sri Lanka's international reserves along with the primary benchmark of reserve adequacy, 'months of imports'.

Figure 1

Gross Official Reserves and Months of Imports (1950-2012)

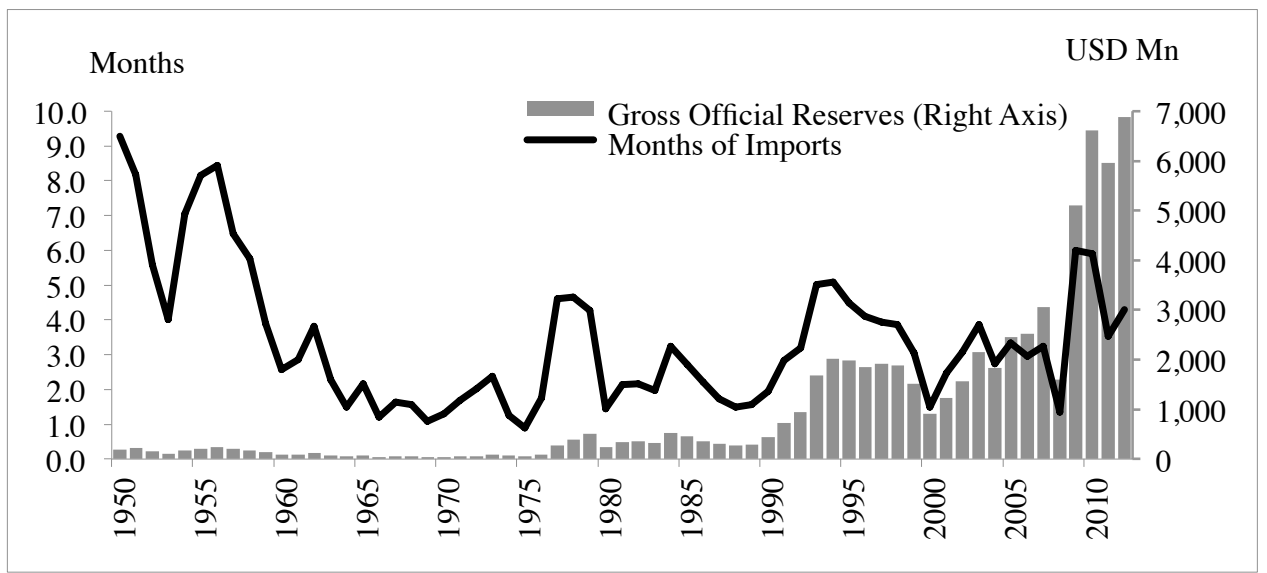


In 1950, Sri Lanka's GOR stood at USD 191 million and reserve adequacy in terms of months of imports ${ }^{10}$ stood at a relatively high level of 9.3 months. Reserves which remained around this level started to deteriorate in the late 1950s due to increased import expenditure. By the mid-1970s, reserves declined gradually to below the USD 50 million level mainly due to the high import growth. As a result, reserve adequacy declined to the lowest level of 0.9 months in 1975. However, with the introduction of economic reforms in 1977 and the relaxation of exchange control regulations pertaining to current account transactions, the reserve position of the country improved considerably over time.

Supported by workers' remittances and private capital inflows, the GOR has increased gradually over the decades, despite the sharp declines in the years 2000 and 2008. In 2000, the higher crude oil prices and increased generation of thermal power caused the import bill to rise significantly, driving the reserves below USD 1 billion. Foreign exchange reserves of Sri Lanka were severely affected during the global financial crisis in 2007-08. CBSL intervened in the foreign exchange market in the presence of mounting pressures on the exchange rate due to withdrawal of short-term investments by foreign investors, the setback in exports, decline in foreign remittances and drying up of capital inflows and the settlement of large oil import bills (CBSL Annual Reports, 2007-2008). As a result, reserves of the country declined from USD 3.1 billion recorded at end 2007 to USD 1.6 billion by end 2008, with corresponding months of imports declining from 3.3 months to 1.4 months by end 2008 .

Figures A1.1 - A1.4 in Appendix 1 show the historical movements (1970 2012) of conventional reserve adequacy measures along with the respective adequacy benchmarks explained under section 2.4. Based on these graphs, it is broadly observed that, except for 'reserves to short term external debt and liabilities', Sri Lanka's international reserve position has remained at adequate levels other than in a few instances when the country was affected by external shocks. In order to arrive at firm conclusions we require a comprehensive analysis and we provide a detailed discussion in Section 3.3 based on the most recent developments.

\subsection{Developing a Foreign Reserves Demand Model for Sri Lanka}

The most common method for estimating the reserve demand in a country is to estimate the best fitting econometric model incorporating the most relevant variables influencing reserves, based on historical data. Such a long-run reserve demand equation could be

10 Based on GOR and imports of merchandise goods (same year). 
used to highlight the country's major motives for holding reserves as well as for estimating the required level of reserves in the future, for a given set of explanatory variables. However, a model developed accordingly is unlikely to give accurate analysis in comparing reserve adequacy of peer countries, as the model will only capture the inherent issues relative to reserves of that particular country, over time.

\subsubsection{The Model}

In order to develop the model for reserve demand, we need to identify the most appropriate determinants of international reserves. To identify the most representative set of explanatory variables capturing the key categories of determinants in establishing a long-run demand function for reserves, we reviewed prior empirical studies and broadly followed the approach of Aizenman and Lee (2007), Park and Estrada (2009), Edison (2003) and Prabheesh, Malathy and Madhumati (2007). Such determinants are summarised in Table 3.

Table 3

Empirical Determinants of Reserve Holdings

\begin{tabular}{ll}
\hline Determinant & Explanatory Variable \\
\hline Economic Size & - Population \\
& - Per Capita GDP \\
Current Account Vulnerability & - Imports \\
& - Trade Openness \\
& - Ratio of Current Account to GDP \\
Capital Account Vulnerability & - Ratio of Capital \& Financial Account to GDP \\
& - Short-term External Debt and Liabilities \\
& - Broad Money \\
\hline Exchange Rate Flexibility & - Standard Deviation (Volatility) of Exchange Rate \\
\hline Opportunity Cost & - Interest Rate Differential \\
\hline
\end{tabular}

It is expected that reserve holdings will rise with respect to economic size. Hence, population and GDP per capita will have a positive impact on reserves. Similarly, a high ratio of import to GDP and trade openness lead to high current account vulnerability and this may in turn induce high reserve demand. In other words, larger external shocks and thus high current account vulnerability raises the demand for reserves. Also, a high ratio of short-term debt to GDP and high broad money to GDP could be associated with higher capital account vulnerability and this may lead to a rise in reserve holdings. Greater exchange rate flexibility would reduce the demand for reserves 
as central banks would no longer need to hold a large stock of reserves to manage the exchange rate. Similarly, a higher opportunity cost is expected to lead to a reduction in reserve holdings because alternative investments become comparatively attractive.

Although the best representative model would contain the 10 variables shown in Table 3, due to data limitations and the possibility of loss of degrees of freedom due to a higher number of variables with relatively fewer number of observations, we are constrained in using all 10 variables in the model. Based on preliminary investigations with regard to data properties and their significance to the model, we selected only 6 explanatory variables to be included in our model to reflect vulnerabilities in the current and capital accounts, exchange rate volatility and the opportunity cost.

Therefore, the reserve demand function for Sri Lanka proposed in our study is specified as:

GOR $=\beta_{0}+\beta_{1} I M P+\beta_{2} O P E N+\beta_{3} S T D+\beta_{4} M S+\beta_{5} X V O L+\beta_{6} O P C O S T+\varepsilon$

Table 4 provides details of the variables and descriptive statistics. Figure A2.1 in Appendix 2 depicts the movements of the variables concerned.

The data used for this study is the quarterly data ranging over Q1-1996 to Q2-2012, extracted from various publications and databases of CBSL and the databases of IMF. The variables GOR, IMP, STD and MS are expressed in millions of US dollars, while OPEN and OPCOST are percentages. XVOL is the standard deviation of the exchange rate series, derived using GARCH $(1,1)$. In the analysis, natural logarithms of the variables GOR, IMP, STD, and MS are used while XVOL and OPCOST are expressed in percentage.

\subsubsection{Methodology}

The majority of prior studies estimate reserve demand functions using the ordinary least squares (OLS) method. However, since many of the relevant variables (for example, reserves, imports, etc.) are likely to be non-stationary, the results of OLS estimates would be inappropriate and at worst spurious. The contributions of Engle and Granger (1987) and Johansen (1988) have provided an opportunity to derive statistically appropriate estimates based on the analyses of cointegrating relationships between non-stationary variables, (i.e., if the variables are found to be non-stationary, then the long-run relationship can be appropriately examined through cointegration tests). To that end, 


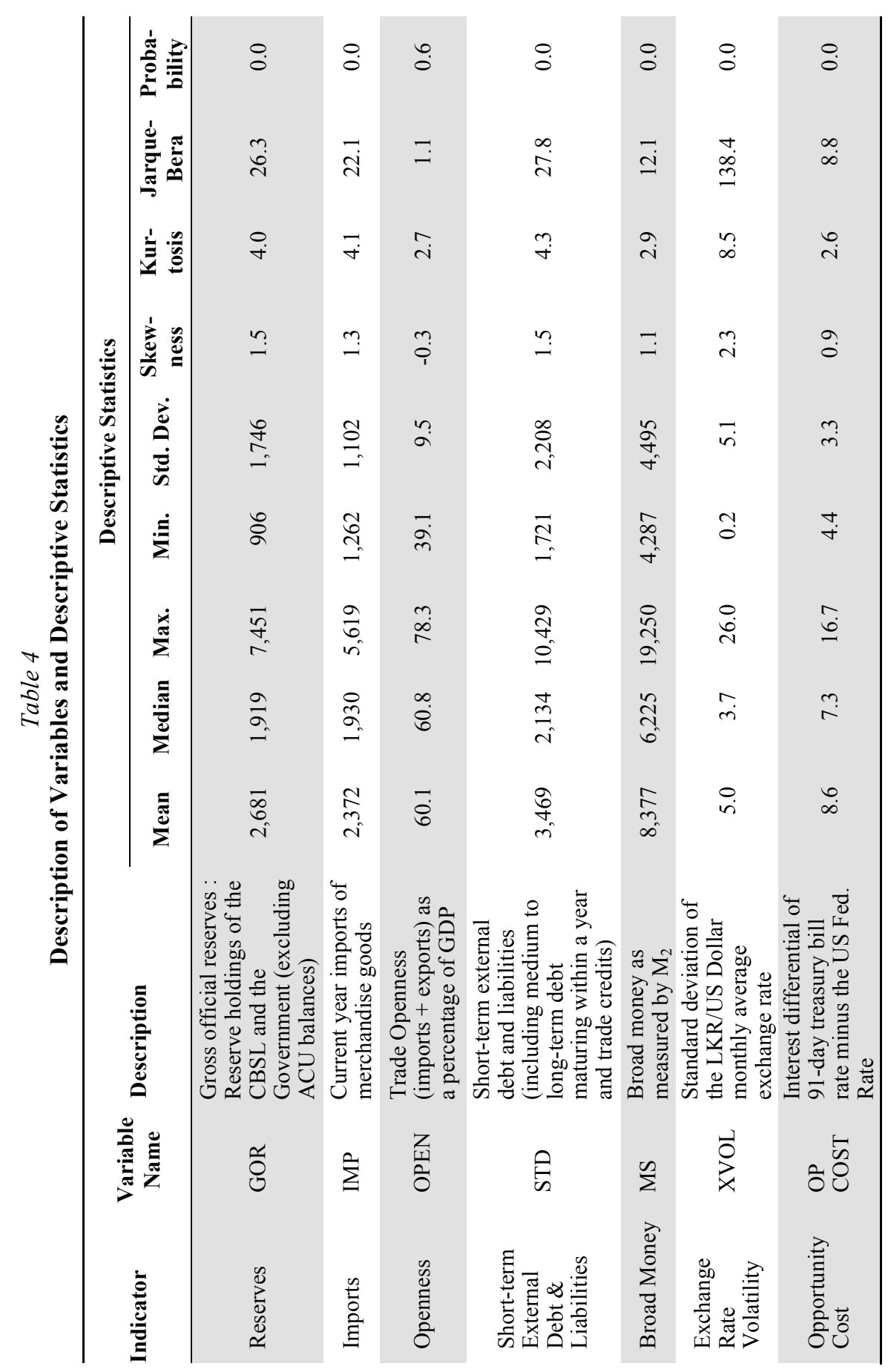


studies of reserve demand rely on Error Correction Models (ECM) and cointegration analysis to provide best estimates. As such, following the prior empirical work in this area, for example, Badinger (2004), Gosselin and Parent (2005) and Prabheesh et al. (2007), among others, we adopt the error correction model and cointegration analysis in this study. We start with the unit root tests and then proceed to estimate Eq. (1) using the cointegration techniques.

\subsubsection{Empirical Results}

As explained above, prior to performing cointegration analysis, it must be first controlled for statistical requirements for the existence of a cointegration relationship. To achieve this, Augmented Dickey-Fuller (ADF) and Phillips-Perron (PP) tests are performed on all variables to find the existence of a unit root. If the variables are found to be nonstationary, then the long-run relationship can be appropriately examined through cointegration tests. Table 5 gives the results of the ADF and PP tests.

Table 5

Unit Root Test Results

\begin{tabular}{llrrrrr}
\hline \multirow{2}{*}{ Variable } & Indicator & \multicolumn{2}{c}{ ADF } & & \multicolumn{2}{c}{ PP } \\
\cline { 3 - 4 } \cline { 6 - 7 } & & Level & 1st Diff & & Level & 1st Diff \\
\hline \multirow{2}{*}{ LNGOR } & Statistic & -0.4339 & -6.7498 & & -1.5492 & -6.0462 \\
& P-Value & 0.8963 & 0.0000 & & 0.8739 & 0.0000 \\
\multirow{2}{*}{ LNOPEN } & Statistic & 0.1908 & -4.7378 & & -0.5743 & -8.2202 \\
& P-Value & 0.9698 & 0.0003 & & 0.8685 & 0.0000 \\
& Statistic & -1.2748 & -3.9588 & & -2.8777 & -19.9770 \\
LNSTD & P-Value & 0.6358 & 0.0030 & & 0.3430 & 0.0000 \\
& Statistic & 1.8497 & -9.3826 & & 2.1628 & -9.3975 \\
& P-Value & 0.9997 & 0.0000 & & 0.9999 & 0.0000 \\
\hline \multirow{2}{*}{ XNMS } & Statistic & 1.6004 & -5.7417 & & 1.6396 & -5.6738 \\
& P-Value & 0.9994 & 0.0000 & & 0.9995 & 0.0000 \\
& Statistic & -2.7466 & -4.5300 & & -2.7466 & -3.9820 \\
& P-Value & 0.2222 & 0.0030 & & 0.2222 & 0.0027 \\
OPCOST & Statistic & -3.1167 & -4.9319 & & -2.5192 & -4.8260 \\
& P-Value & 0.1113 & 0.0008 & & 0.3182 & 0.0012 \\
\hline
\end{tabular}

Note: Critical values are taken from MacKinnon, 1991 
The ADF and PP test the null hypothesis of "non-stationarity" (i.e. the series has a unit root) against the alternative of "stationarity". At levels, the test statistics of both $\mathrm{ADF}$ and PP for all seven variables (GOR, IMP, MS, OPEN and STD are in logs) are not significant at the $5 \%$ level, and hence the null hypothesis of existence of a unit root cannot be rejected. This indicates that all the data series are non-stationary. However, at differences, both tests indicate that all variables are significant at the $5 \%$ significance level. From the results of the ADF and PP above, it can be seen that all variables are non-stationary and therefore, Johansen's Maximum Likelihood (ML) test can be performed to examine the existence of any cointegrating relationship between the variables. In performing the Johansen's ML cointegration test on the seven variables, first, the unrestricted VAR is estimated to find the lag length, for which the Akaike Information Criteria (AIC) and the Schwaz Information Criteria (SIC) are used. Both AIC and SIC are minimised at level 2 and therefore lag 2 is selected as the optimal lag length. The summary of cointegration tests is reported in Table 6 .

Table 6

Cointegration Test Results

\begin{tabular}{ccccc}
\hline Null Hypothesis & $\boldsymbol{\lambda}$-Trace & $\boldsymbol{\lambda}$-Trace 5\% CV & $\boldsymbol{\lambda}$-Max & $\boldsymbol{\lambda}$-Max $\mathbf{5 \%} \mathbf{C V}$ \\
\hline $\mathrm{r}=0$ & 88.66 & 69.81 & 42.23 & 33.87 \\
$\mathrm{r} \leq 1$ & 46.42 & 47.85 & 28.31 & 29.58 \\
\hline
\end{tabular}

The test results show that both test statistics, Trace test ( $\lambda$-Trace) and Maximum Eigen Value ( $\lambda$-Max), reject the null hypothesis at $r=0$, but not at $r=1$ at the $5 \%$ level of significance. This indicates that there exists one cointegrating vector between the variables. Therefore, an error correction model was specified and resultant normalized cointegrating coefficients (with respect to GOR) are presented in Table $7 .{ }^{11}$

11 Following Aizenman and Lee (2007), a crisis dummy was introduced for the quarters Q4-2000 to Q3-2001 and Q3-2008 to Q2-2009 when the country's external sector was affected and reserves slumped due to the global economic downturn in 2001 and the global financial crisis in 2008, respectively. However, it was found that the crisis dummy was not significant at the $5 \%$ level, and therefore the crisis dummy was excluded in deriving the model. 
Table 7

Normalised Cointegrating Coefficients

\begin{tabular}{|c|c|c|c|c|c|c|c|}
\hline & LNGOR & LNIMP & LNOPEN & LNSTD & LNMS & XVOL & OPCOST \\
\hline$\beta$ Coefficient & 1.0000 & 25.7922 & -12.2335 & -4.4365 & -18.8787 & -0.0546 & -0.0763 \\
\hline $\begin{array}{l}\text { Standard } \\
\text { Errors }\end{array}$ & & 4.8196 & 5.4845 & 2.2236 & 5.4783 & 0.0705 & -0.0705 \\
\hline T-Statistic & & $5.3515^{*}$ & $-2.2306^{*}$ & $-1.9952 *$ & $-3.4461 *$ & -0.7748 & -1.0831 \\
\hline
\end{tabular}

* Significant at $5 \%$ level

The t-statistics of each variable in the normalised equation (Table 7) show that, imports (LNIMP), trade openness (LNOPEN), short term debt and liabilities (LNSTD) and money supply (LNMS) are significant at the 5\% level, whereas exchange rate volatility (XVOL) and opportunity cost of holding reserves (OPCOST) are not. Meanwhile, the normalised equation shows that the expected signs of the variables in influencing demand for reserves hold true for all variables except for imports (LNIMP), exchange rate volatility (XVOL) and opportunity cost of holding reserves (OPCOST). Since the two variables, XVOL and OPCOST are anyway not significant at the 5\% level, these two variables should be dropped from the reserve demand equation.

Table 8

Error Correction Model

$\begin{array}{lllllll}\text { D(LNGOR) } & \text { D(LNIMP) } & \text { D(LNOPEN) } & \text { D(LNSTD) } & \text { D(LNMS) } & \text { D(XVOL) } & \text { D(OPCOST) }\end{array}$

\begin{tabular}{lrrrrrrr}
\hline $\begin{array}{l}\text { C Coefficient } \\
\text { Standard }\end{array}$ & -0.1217 & -0.0341 & -0.0160 & 0.0005 & -0.0008 & -0.3692 & 0.2885 \\
$\begin{array}{l}\text { Errors } \\
\text { T-Statistic }\end{array}$ & -5.0219 & 0.0120 & 0.0123 & 0.0081 & 0.0036 & 0.2742 & 0.1553 \\
\hline
\end{tabular}

* Significant at $5 \%$ level

In the ECM (Table 8), we see the coefficient of the Error Correction Term (ECT) of D(LNGOR) (-0.1217), which indicates the speed of adjustment to the long-run equilibrium is significant. However, this implies a rather slow adjustment to equilibrium 
(Badinger, 2004) and only $12 \%$ of the deviation from equilibrium is eliminated within one quarter, taking around 2 years to reach long-term equilibrium. Hence, the model indicates a slower response from the authorities when the reserves deviate from the desired level. We further observe that trade openness (LNOPEN), short-term debt and liabilities (LNSTD) and broad money (LNMS) are weakly exogenous to the model.

Since the model indicated that exchange rate volatility is not significant to the reserve demand function, it is important to verify whether it holds true in practice as well. Sri Lanka's exchange rate policy till 2011 was mainly focused on maintaining stability in the domestic foreign exchange market and avoiding undue volatility in the exchange rate. In the presence of excessive foreign inflows to the country, the CBSL has been active in absorbing foreign exchange from the market to prevent undue appreciation in the exchange rate while supporting to maintain export competitiveness. Similarly, during the recent global financial crisis, in the presence of sudden outflows of short-term investments, the CBSL opted to utilise its reserves to avoid undue depreciation in the exchange rate. Therefore, these could be the reasons for the non-significance of 'exchange rate volatility (XVOL)' to the model. Further, this observation does not contradict prior literature on other countries. For example, Aizenman and Lee (2007) show exchange rate volatility could be insignificant across models. In particular, they observe some significance only when the Asia-specific crisis dummy is used in their models for 53 countries. Cheung and Qian (2009) also highlight that although international reserve holding is found to be negatively affected by exchange rate volatility, the impact of exchange rate volatility could be zero.

The variable 'opportunity cost (OPCOST)' being not significant to the model implies that Sri Lanka's accumulation of foreign reserves is less sensitive to the opportunity cost of holding reserves.

The change in expected sign in imports (LNIMP) in the model could be due to the fact that although theoretically we should hold a higher level of reserves when imports tend to be high, actual circumstances have led reserves to decline due to the utilisation of reserves to finance the increasing import bill, contradicting the precautionary motive for holding reserves. In fact the negative coefficient for imports is not surprising when we consider prior empirical literature. For example, in a survey article, Bahmani-Oskooee and Brown (2002) argue that imports report mixed signs across empirical literature of reserve demand. In particular, although a positive coefficient is generally expected, negative coefficients have been observed for the variables that capture the impact of imports, for example in Huang (1995), Badinger (2004), Sehgal and Shrama (2008) among others. Specifically, based on the evidence for China, Huang 
(1995) shows that although most of the country's foreign exchange is counted as reserves, it will flow in the opposite direction to imports. Hence Huang argues that imports no longer reflect indirect transactional requirements for reserves, and instead, they reflect the opposite flows of goods and money in and out of the country. He further argues there is a concern that while imports affect reserves, reserves could also affect imports.

Therefore, the resultant long-run model for reserves demand for Sri Lanka can be specified as follows:

$\operatorname{Ln}(G O R)=-48.8-25.8 \operatorname{Ln}(I M P)+12.2 \operatorname{Ln}(O P E N)+4.4 \operatorname{Ln}(S T D)+18.9 \operatorname{Ln}(M S)$

According to this equation it can be seen that a $1 \%$ increase in imports will lead the reserves to decline by $25.8 \%$, while a $1 \%$ increase in each of the variables, trade openness (OPEN), short-term debt and liabilities (STD) and broad money (MS) will increase reserves by $12.2 \%, 4.4 \%$ and $18.9 \%$, respectively.

Using the estimated reserves demand model, the required level of reserves in the future for an appropriate set of explanatory variables can be forecasted. The reserves estimated accordingly for the third and fourth quarters of 2012 are given in Table 9.

Table 9

Actual Reserves Vs. Estimated Reserves Demand as per the Model

\begin{tabular}{cccc}
\hline Period & $\begin{array}{c}\text { Actual } \\
\text { GOR } \\
\text { (USD Mn) }\end{array}$ & $\begin{array}{c}\text { GOR Estimated as per } \\
\text { Model } \\
\text { (USD Mn) }\end{array}$ & $\begin{array}{c}\text { Excess } \\
\text { Reserves } \\
\text { (USD Mn) }\end{array}$ \\
\hline Q3 - 2012 & 7,054 & 7,827 & -733 \\
Q4 - 2012 & 6,877 & 5,933 & 944 \\
\hline
\end{tabular}

It can be seen that actual reserves held by Sri Lanka in the third quarter is short by USD 733 million while in the fourth quarter it is in excess by USD 944 million from the reserves estimated by the model. 


\subsection{Assessing International Reserve Adequacy in Sri Lanka: The IMF's New Risk-Weighted Metrics}

\subsubsection{Features and Drawbacks in Conventional Metrics}

To assess reserves adequacy for comparison purposes, we first use the conventional metrics based on simple rules of thumb such as 3-months of imports, $100 \%$ coverage of short-term debt and liabilities (STD) and $20 \%$ of broad money $\left(\mathrm{M}_{2}\right)$. Although these benchmarks are internationally accepted standards, they focus only on specific aspects of external vulnerability. Therefore these conventional metrics are often used individually or in combination, such as the highest of: 3-months of imports; $100 \%$ of STD; $20 \%$ of $\mathrm{M}_{2}$.

Figure 2 depicts the actual GOR of Sri Lanka against the required (or adequate) level of reserves as per conventional international standards, i.e., 3-months of imports and $100 \%$ coverage of STD and $20 \%$ of $\mathrm{M}_{2}$, over the past 15 years.

Figure 2

\section{Actual Reserves (GOR) Vs. Required Level of Reserves as per the Conventional Metrics}

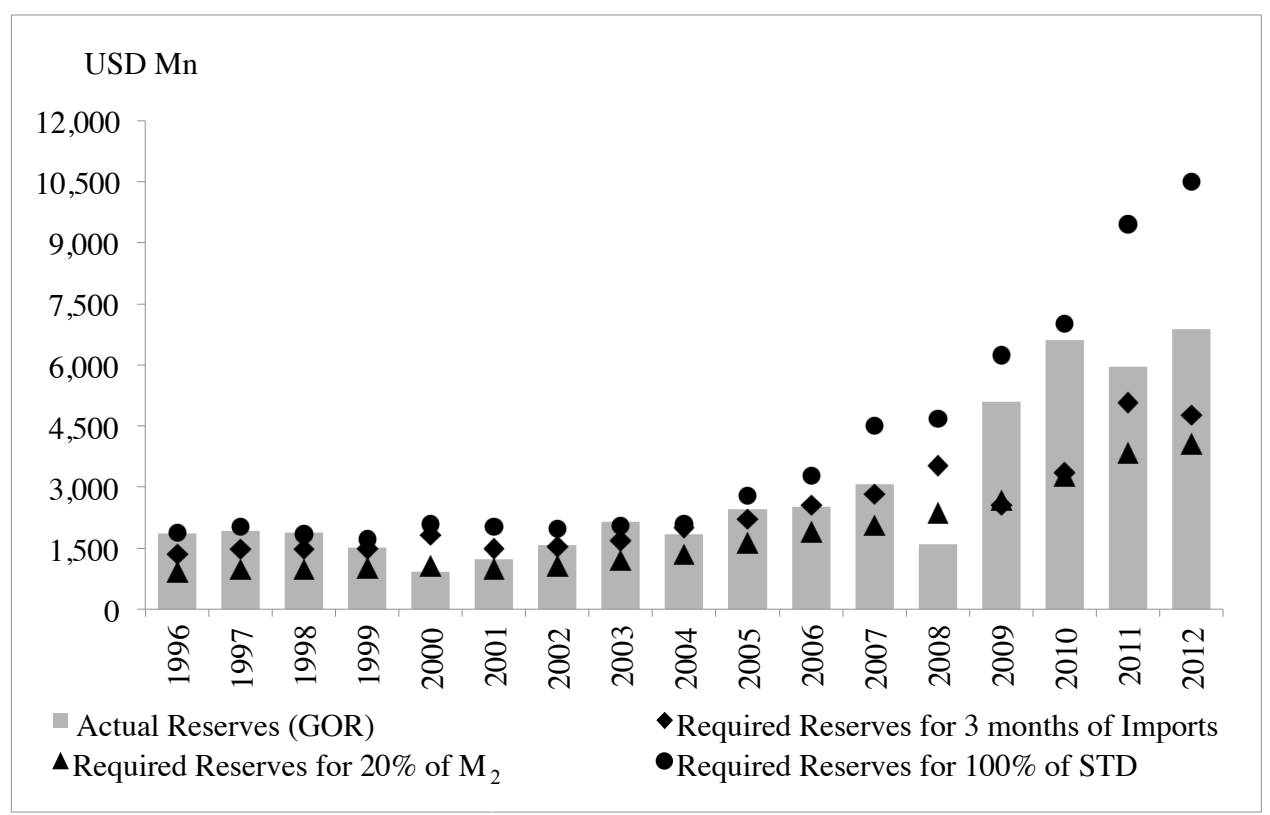


It is observed that reserves have increased gradually over the years, except in the years 2000, 2008 and 2011. In 2000 and 2008, reserves slumped when Sri Lanka's external sector was adversely affected by the two episodes of the global economic downturn in the respective years, and actual reserves in those two years were inadequate in terms of all three conventional metrics. In 2011, although the reserves were utilized to ease market pressure for foreign exchange in the presence of a widening trade deficit on account of an increased oil import bill, (CBSL Annual Report, 2011), we observe that the reserves were within the levels required, at least by two of the three benchmarks.

In general, Sri Lanka has maintained reserves in excess of 3-months of imports over the past years, except in the years 2000, 2001, 2004 and 2008. With respect to the broad money benchmark of $20 \%$ of $\mathrm{M}_{2}$, reserves have broadly remained above the required level except in the two exceptional years, 2000 and 2008. However, with respect to adequacy in terms of STD, reserves have always remained lower than the standard benchmark of $100 \%$ of STD. This gap has widened in recent years. This could mainly be due to the opening up of the Treasury bond and bill market to foreign investors in 2006 and 2008, respectively. The reserve adequacy in terms of $100 \%$ STD has reached the highest level of USD 10.5 billion in 2012 from the previous record level of USD 9.5 billion in 2011. By end 2011, Treasury bonds with tenors of 1-20 years accounted for around $70 \%$ (USD 1.7 billion) of the total foreign holdings of treasury securities. This could be one of the reasons for the higher outstanding value of STD, apart from the USD 500 million sovereign bond which was due for settlement in October 2012. Considering the long term maturity aspect of Treasury bonds, if we exclude it from the outstanding STD at end 2011, the reserves requirement of $100 \%$ of STD would only be equivalent to around USD 7.8 billion (as opposed to the USD 9.5 billion in Figure 2). Similarly, by end 2012, outstanding Treasury bonds with 1-20 year tenors amounted to USD 2.5 billion ( $80 \%$ of the Treasury securities portfolio), and STD excluding such bonds amounted to USD 8.0 billion (contrary to USD 10.5 billion in Figure 2).

In this context, it is worth considering whether conventional metrics should be used in entirety, or any judgmental factors could as well be incorporated in deciding the adequate level of reserves to be held by a country. This could be one of the reasons for countries to move away from following the conventional metrics in their reserve holding decisions, and instead, use more broad-based risk weighted metrics.

\subsubsection{New Risk-Weighted Reserve Adequacy Metrics Proposed by the IMF}

The above mentioned drawbacks of conventional metrics were addressed by the IMF in developing a more broad-based risk-weighted metrics for assessing reserve adequacy 
(IMF, 2011). Although this metrics is still being reviewed and is subject to academic discussion, it has been recommended as a more representative and broad-based measure of assessing reserve adequacy.

The scope of the new metrics developed by IMF has entirely been focused on the precautionary aspect of holding reserves. This reflects the key distinguishing characteristic of reserves, namely, their availability and liquidity, for potential balance of payments needs. Metric-based approaches focus on adequacy in the face of potential balance of payments pressures, but they specify that judgment is required on the intensity of potential shocks the country would face and the resulting level of reserves that should be maintained. IMF (2011) specifies that although the judgment necessarily involves an arbitrary element based on past experience, this approach also has the advantage of simplicity, tractability and transparency. In the IMF (2011), two approaches have been produced to assess reserve adequacy for emerging countries (EMs) and low-income countries (LICs) separately. To assess the reserve adequacy of Sri Lanka, we use the metrics developed for EMs.

The IMF's new proposal for developing a reserve adequacy metrics for EMs is based on a two-stage 'risk-weighted' approach as discussed below.

\section{Stage 1: Identifying Risk Factors and Assigning Weights}

In the first stage, the metrics is developed based on observed foreign exchange outflows during periods of exchange market pressures (EMP) ${ }^{12}$. The IMF (2011) cites that studies of individual crisis episodes show balance of payments pressure from a range of potential sources of risks, emanating from both financial and current account variables. They have identified four specific sources of such drains, namely, export earnings (X), short-term debt (STD), other portfolio liabilities (OPL) and broad money $\left(\mathrm{M}_{2}\right)$.

In the event of a drop in external demand, there will be a loss of earnings expected from exports $(\mathrm{X})$. Although imports expenditure is the most commonly used current account variable, it is not directly affected by a downfall of external demand, and, as imports usually depend on available financing, during crisis periods, imports tend to fall, supporting the balance of payments to some extent. Therefore, exports as an indicator is more responsive to external shocks than imports. Short-term debt (STD) and

12 EMP measures the total excess demand for a currency in international markets as the exchange rate change that would have been required to remove this excess demand in the absence of exchange market intervention, given the expectations generated by the exchange rate policy actually implemented (Weymark, 1995). 
other portfolio liabilities (OPL) are both indicators of external liabilities and account for additional observed drains. In a crisis situation, short-term debt as well as equity is more prone to be withdrawn fast. This may ultimately lead not only to a depreciation of the exchange rate, but equity prices too may fall. To capture capital flight risk, broad money as measured by $\mathrm{M}_{2}$ has been used to represent the stock of liquid domestic assets that could be sold and transferred into foreign assets during a crisis, (IMF, 2011).

In deriving the risk weights, the IMF has selected a sample of 48 countries covered in the IMF's 'Vulnerability Exercise' for EMs over the period of 1990-2009, (Assessing Reserve Adequacy - Supplementary Information, IMF, 2011). The risk weights have been based primarily on tail event outflows associated with periods of EMP. The potential loss of foreign exchange during such periods has been computed as annual percentage losses of the above identified sources of drains, namely, X, STD, OPL and $\mathrm{M}_{2}$. Such probability distributions are presented in Figure 3.

Figure 3

\section{Risk-Weights against Different Potential Foreign Exchange Drains}
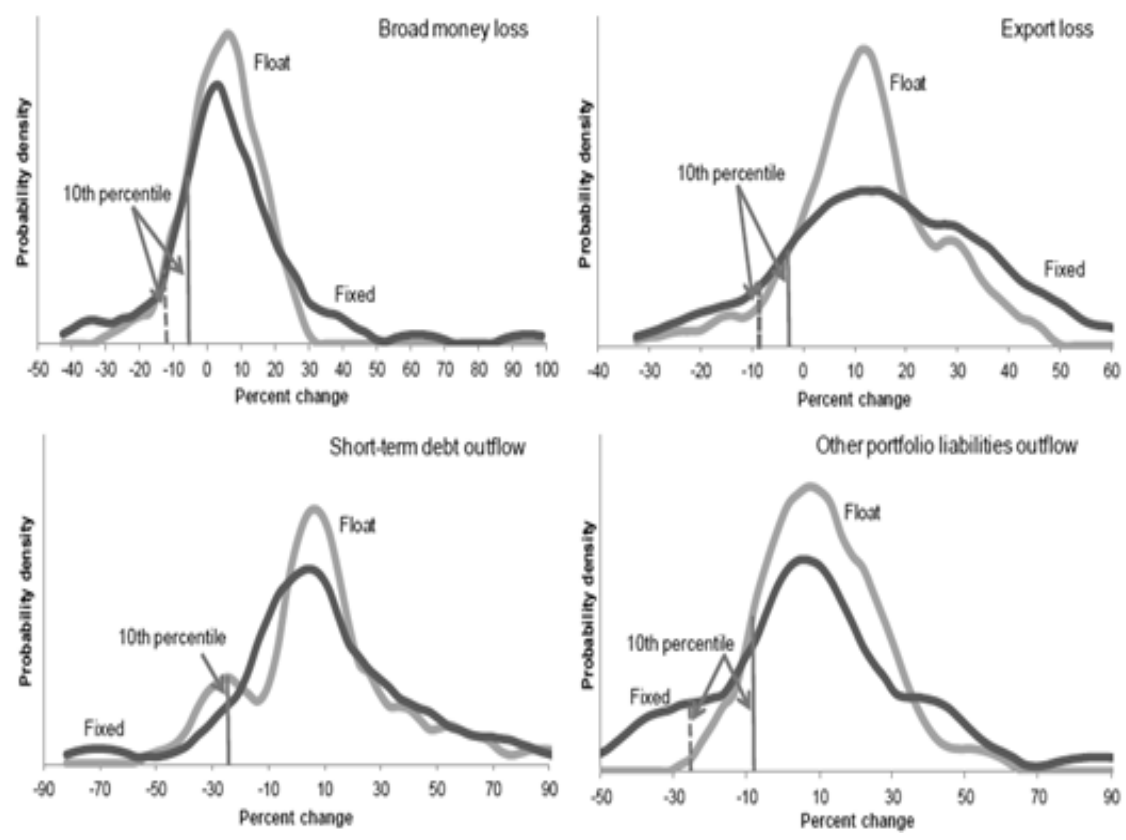

Source: Extracted from IMF (2011) 
The proposed approach has focused on drains observed at the $10^{\text {th }}$ percentile of each of the distributions (Figure 3 ). The $10^{\text {th }}$ percentile has been chosen as a reasonable balance between data limitations and the need to test reasonably severe shocks (IMF, 2011). Such probability distributions have been estimated separately for fixed and floating exchange rate regimes and two sets of weights have been derived for the two exchange rate regimes. For example, in "other portfolio liabilities outflows" (panel 4 of Figure 3 ), the probability at $10^{\text {th }}$ percentile for the fixed exchange rate regime gives a percentage change of a drain of around $28 \%$. This broadly means that $28 \%$ of "other portfolio liabilities outflows" are needed to insure against $90 \%$ of the risk during an EMP episode. Estimated risk weights derived accordingly for each exchange rate regime by IMF are given in Table 10 .

Table 10

$10^{\text {th }}$ Percentile Outflows during Exchange Market Pressure Events

\begin{tabular}{lcccc}
\hline & Exports (X) & $\begin{array}{c}\text { Broad Money } \\
\left(\mathbf{M}_{\mathbf{2}}\right)\end{array}$ & $\begin{array}{c}\text { Short-term Debt } \\
\text { (STD) }\end{array}$ & $\begin{array}{c}\text { Other Portfolio } \\
\text { Liabilities (OPL) }\end{array}$ \\
\hline Fixed & 8.9 & 12.4 & 24.4 & 27.6 \\
Floating & 2.3 & 7.1 & 24.4 & 9.2 \\
\hline
\end{tabular}

Source: IMF Staff calculations

With further adjustments based on scenario analysis and judgmental factors, the following weights have been proposed by the IMF for the fixed and floating exchange rate regimes. Accordingly, the required levels of reserves under the risk-weighted metrics (R-Requirement) for respective exchange rate regimes are defined as:

$$
\begin{aligned}
& \text { R-Requirement }_{\text {(Fixed) }}=10 \% \text { of } \mathrm{X}+10 \% \text { of } \mathrm{M}_{2}+30 \% \text { of STD }+15 \% \text { of OPL } \\
& \text { R-Requirement }_{\text {(Floating) }}=5 \% \text { of } \mathrm{X}+5 \% \text { of } \mathrm{M}_{2}+30 \% \text { of STD }+10 \% \text { of OPL }
\end{aligned}
$$

It could be seen that R-Requirement for fixed exchange rate regime (Eq. 3) carries higher weights relative to that of the floating exchange rate regime (Eq. 4). This is mainly due to the need of maintaining additional reserves to defend the fixed exchange rate during a crisis. 


\section{Stage 2: Determining the Level of Adequacy}

The second stage of the IMF's approach is to determine the reserve coverage or reserve adequacy ratio which is the actual level of GOR a particular country should hold relative to the risk-weighted metrics. Therefore, the reserve adequacy ratios (R-Adequacy Ratios) for respective exchange rate regimes are given by:

R-Adequacy Ratio $_{\text {(Fixed) }}=\left\{\right.$ GOR / R-Requirement $\left._{\text {(Fixed) }}\right\} * 100$

R-Adequacy Ratio $_{\text {(Floating) }}=\left\{\right.$ GOR / R-Requirement (Floating) $_{*} * 100$

In deciding a benchmark for reserve adequacy ratio, the IMF has studied past crisis episodes and used three approaches to help inform this judgment, focusing on crisis prevention, crisis mitigation, and observed reserve losses, and derived an adequate level of reserves to be held by a country. The IMF (2011) states that their results highlight the necessity of a high degree of judgment but taken together suggest a coverage in the region of $100 \%-150 \%$ of the metrics that might be regarded as adequate for a typical country. This means that if the reserve adequacy ratio is in the range of $100 \%-150 \%$, we could be satisfied that country's reserves are adequate to avoid or mitigate the adverse implications of an external shock. However, IMF (2011) also states that even if $100 \%-150 \%$ of reserves is accepted as an adequate range, it would not preclude countries from wanting to hold more or less than this, depending on their particular circumstances and degree of risk aversion.

The proposed reserves adequacy metrics is still in the developing stage, providing guidance only at the most general level and the IMF recommends that it best be regarded as a potential advance on existing metrics. Therefore, the IMF suggests that additional experience and analysis can yet be brought to bear both on what weights should be put on different sources of risk and also on how much of the resulting metrics is reasonable to hold and particularly considerable judgment would be required in application of this metrics to individual countries. The IMF has highlighted a few examples:

i. If foreign STD is primarily held by foreign parents, then the weight on STD may be reduced, while a higher weight should be assigned if STD is mainly raised from international capital markets. Similarly a large share of trade credits within STD might imply less need for reserve cover mainly owing to their ability for being rolled over during the absence of a crisis. However, IMF, 2000, carries a 
contradictory view. Although in the early periods, trade credits have not been included in the STD, this paper has cited that the experience in the recent crisis episodes has underscored that during severe crises all short-term lending has been drastically curtailed, as banks and other investors have sought to limit their overall country exposure. A comprehensive concept of debt that includes trade credits is therefore most useful as a general measure.

ii. The weight on exports might need to be much higher for countries that export commodities, which are subject to wide price fluctuations.

iii. The weight on $\mathrm{M}_{2}$ could be reduced (or even eliminated) where effective capital controls that would prevent capital flight are in place.

iv. Within the floating rate classification, a country that is willing or able to tolerate large fluctuations in the exchange rate might be comfortable holding a lower reserve coverage of the metrics, whereas a country that desires to avoid a significant depreciation might want to hold more.

\subsubsection{Application of the IMF's Risk-Weighted Metrics to Assess Reserve Adequacy for Sri Lanka}

For assessing reserve adequacy under the new metrics for Sri Lanka, risk weights computed by the IMF for EMs are directly applied in this study. It would be ideal to have derived a new set of country-specific risk weights, but, since that should be done by conducting out a comprehensive survey, and to our knowledge, this being the first attempt of research in this area for Sri Lanka, we have applied the same weights that IMF has researched and derived for emerging economies, to estimate reserve adequacy for Sri Lanka.

In assessing reserve adequacy for Sri Lanka based on new metrics, annual data for the period from 1996 to 2012 for export earnings (X), short-term debt and liabilities (STD), other portfolio liabilities (OPL) and broad money $\left(\mathrm{M}_{2}\right)$ were selected. The variable $\mathrm{X}$ captures earnings from exports of merchandise goods, while broad money as measured by $\mathrm{M}_{2}$ is considered. In estimating the STD, in addition to Treasury bills and bonds and trade credits, all medium and long-term debt of the government and the private sector, that are maturing within a year, have also been added to the STD. OPL mainly includes the foreign equity holdings at the Colombo Stock Exchange. 
In deriving the reserve adequacy ratio, first, the reserve requirement under the risk-weighted metrics for both exchange rate regimes are estimated using equations (3) and (4), and reserve adequacy ratio for both exchange rate regimes are then computed using equations (5) and (6). Table 11 presents the GOR, reserve requirement and reserve adequacy computed for Sri Lanka for each exchange rate regime for the period 1996-2012.

Table 11

Reserve Adequacy under each Exchange Rate System

\begin{tabular}{ccccrc}
\hline & $\begin{array}{c}\text { Gross } \\
\text { Official } \\
\text { Year }\end{array}$ & \multicolumn{2}{c}{$\begin{array}{c}\text { Reserve Requirement } \\
\text { (USD Mn) }\end{array}$} & \multicolumn{2}{c}{$\begin{array}{c}\text { Reserve Adequacy Ratio } \\
\text { (\%) }\end{array}$} \\
\cline { 3 - 6 } & (USD Mn) & Fixed & Floating & Fixed & Floating \\
\hline 1996 & 1,855 & 1,476 & 1,028 & 125.7 & 180.5 \\
1997 & 1,922 & 1,620 & 1,123 & 118.6 & 171.1 \\
1998 & 1,892 & 1,564 & 1,065 & 121.0 & 177.6 \\
1999 & 1,519 & 1,522 & 1,025 & 99.8 & 148.1 \\
2000 & 912 & 1,729 & 1,180 & 52.7 & 77.2 \\
2001 & 1,231 & 1,613 & 1,113 & 76.3 & 110.6 \\
2002 & 1,565 & 1,629 & 1,117 & 96.1 & 140.1 \\
2003 & 2,147 & 1,789 & 1,212 & 120.0 & 177.1 \\
2004 & 1,834 & 1,962 & 1,308 & 93.5 & 140.2 \\
2005 & 2,458 & 2,407 & 1,641 & 102.1 & 149.7 \\
2006 & 2,526 & 2,795 & 1,917 & 90.4 & 131.7 \\
2007 & 3,063 & 3,371 & 2,398 & 90.8 & 127.7 \\
2008 & 1,594 & 3,542 & 2,497 & 45.0 & 63.9 \\
2009 & 5,097 & 4,221 & 3,097 & 120.7 & 164.5 \\
2010 & 6,610 & 5,186 & 3,744 & 127.5 & 176.6 \\
2011 & 5,958 & 6,397 & 4,714 & 93.1 & 126.4 \\
2012 & 6,877 & 6,867 & 5,125 & 100.2 & 134.2 \\
\hline
\end{tabular}

Sources: CBSL and Estimates by Authors

In analysing the reserve adequacy as per the risk weighted metrics, the exchange rate regime of Sri Lanka should first be identified. Sri Lanka moved to an independent floating exchange rate regime in 2001 from the managed floating system that it had followed since economic liberalization in 1977. Although the country follows a de jure floating exchange rate regime since 2001, the IMF's-Annual Report on Exchange Arrangements and Exchange Restrictions (AREAER) (1996-2012), which carries out in-depth analyses of the exchange rate systems of member countries, has classified 
Sri Lanka as having followed a pegged or stabilised exchange rate system in certain years. Therefore, further analysis was carried out to ascertain how daily spot exchange rates have varied over the period under review of this study. A country in general is said to be following a pegged (or stabilised) exchange rate system, if the exchange rate fluctuates within a narrow margin of $\pm 1 \%$ around a central rate for at least six months. Table 12 presents the de facto exchange rate regime as classified by the IMF, and the classification as per our analysis based on the above definition.

\section{Table 12}

\section{Classification of Exchange Rate Regime of Sri Lanka}

\begin{tabular}{|c|c|c|}
\hline Year & $\begin{array}{l}\text { IMF - AREAER } \\
\text { Classification }\end{array}$ & $\begin{array}{c}\text { Classification based on Authors' } \\
\text { Analysis * }\end{array}$ \\
\hline 1996 & Managed floating & Floating \\
\hline 1997 & Managed floating & Floating \\
\hline 1998 & Managed floating & Floating \\
\hline 1999 & Crawling band & Floating \\
\hline 2000 & Crawling band & Floating \\
\hline 2001 & Managed floating & Floating \\
\hline 2002 & Managed floating & Floating \\
\hline 2003 & Independent floating & Floating \\
\hline 2004 & Independent floating & Floating \\
\hline 2005 & Independent floating & Floating \\
\hline 2006 & Managed floating & Floating \\
\hline 2007 & Managed floating & Floating \\
\hline 2008 & Conventional peg & Stabilised arrangement \\
\hline 2009 & Floating & Floating \\
\hline 2010 & Stabilised arrangement & Stabilised arrangement \\
\hline 2011 & Crawl-like arrangement & Stabilised arrangement \\
\hline 2012 & Floating & Floating \\
\hline
\end{tabular}

Sources: IMF - AREAER (1996-2012) and Authors' Analysis

* If the exchange rate fluctuates within a margin of less than $\pm 1 \%$ around a central rate for at least six months, then the regime is classified as "Pegged" (or Stabilised) and, if otherwise as "Floating". 
Based on the criteria specified, we notice that in the years, 2008, 2010 and 2011, the exchange rate of LKR/USD has moved within a narrow margin of $\pm 1 \%$ around a central rate at least for six months, and therefore it is reasonable to conclude that during these three years Sri Lanka has not followed a floating exchange rate system. This is consistent with IMF's AREAER classification that Sri Lanka has followed a more stabilised exchange rate system during the said years. Therefore, from the reserve adequacy ratios that were estimated for both exchange rate systems (Table 11), we decided to select the respective ratios capturing the regimes that are based on the above findings (Table 12). Accordingly, reserve adequacy ratios applicable for fixed exchange rate regime (which is more rationally termed as stabilised arrangement) were selected for the years 2008, 2010 and 2011, while ratios for the floating exchange rate system were selected for the remaining years. Figure 4 depicts the reserve adequacy ratios selected accordingly, with labels "FL" for the Floating Exchange Rate Regime and "SA" for the Stabilised Arrangement to highlight the exchange rate system followed in that particular year.

Figure 4

\section{Reserve Adequacy Ratios as per the New Risk-Weighted Metrics (with Respective Exchange Rate Systems)}

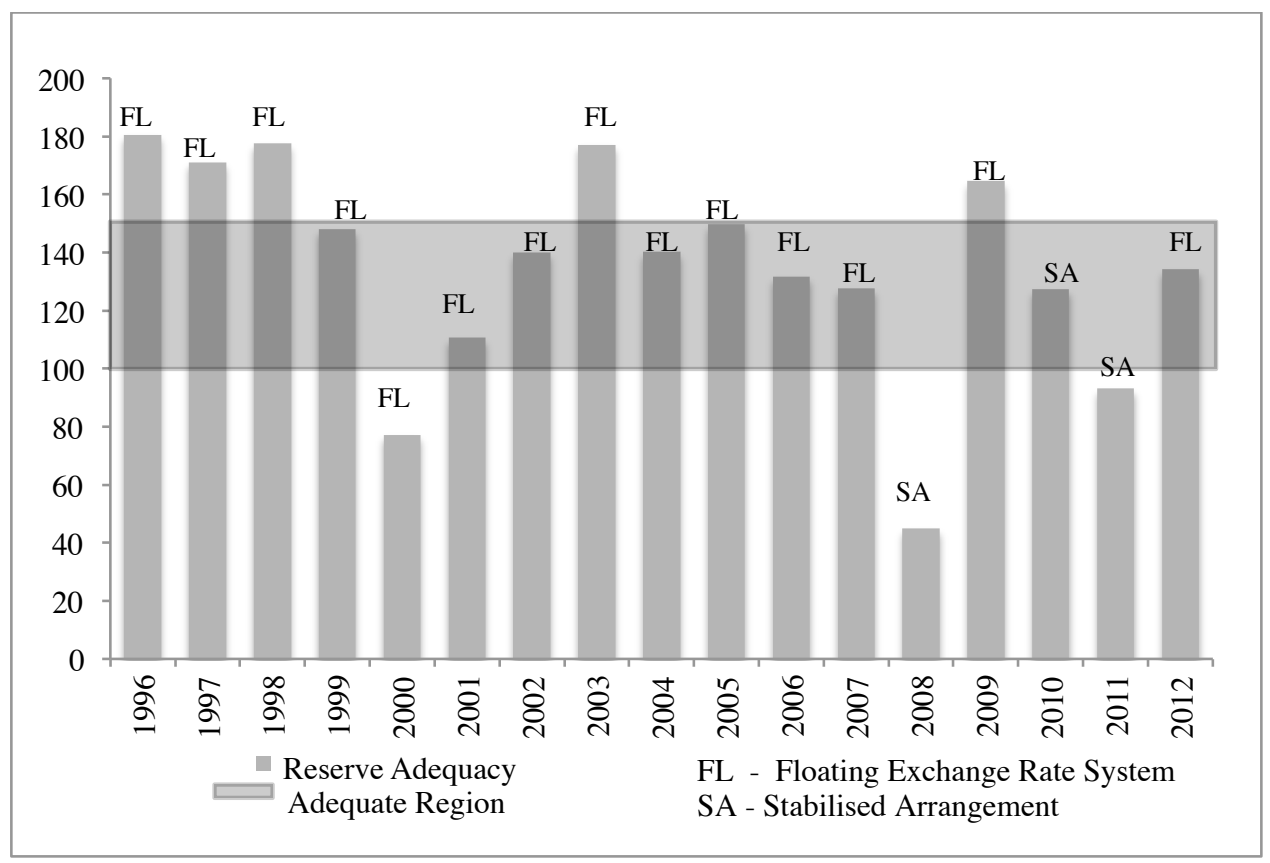


As per the IMF (2011), reserves are said to be adequate if the reserve adequacy ratio is in the range of $100 \%-150 \%$. From Figure 4, it can be seen that Sri Lanka has had adequate ratios above 100\% throughout, except in the years 2000, 2008 and 2011. Lower ratios in years 2000 and 2008 were due to the decline in the country's reserves amidst the two respective episodes of global economic downturns. However, the lower ratio in 2011 was mainly due to the utilisation of reserves to ease the heavy foreign exchange demand in the domestic market emanated from the high volume of petroleum import bills due for settlement (CBSL Annual Report, 2011).

\subsubsection{Comparison of Reserve Adequacy in terms of Conventional and New Risk- Weighted Metrics}

Finally, in order to assess Sri Lanka's reserve adequacy relative to conventional metrics and the new risk-weighted metrics, Figure 5 is constructed. Figure 5 shows actual GOR against: (i) Maximum reserves required as per the conventional metrics, i.e., $100 \%$ of STD, and (ii) Reserves requirement equivalent to $100 \%$ of the new risk-weighted metrics $^{13}$.

From this figure, it can be well observed that even though actual reserves were low throughout, in comparison to the conventional measure of $100 \%$ of STD, in terms of the new metrics, actual reserves in Sri Lanka have been in excess of $100 \%$ of the new metrics except for the years 2000, 2008, and 2011. IMF (2011) also reveals that the new metrics is a better yardstick against which to measure reserves from a precautionary perspective than the conventional metrics - whether the latter are examined in isolation or together. Hence according to the new risk-weighted metrics, Sri Lanka has broadly held adequate levels of foreign exchange reserves throughout the reference period.

13 Following the findings of Section 3.3.3, new metrics values for the years 2008, 2010 and 2011, are for "Stabilised Arrangement" while values applicable for "Floating Rate Regime" are considered for the remaining years. 
Figure 5

\section{New Metrics Vs. Maximum of Conventional Metrics}

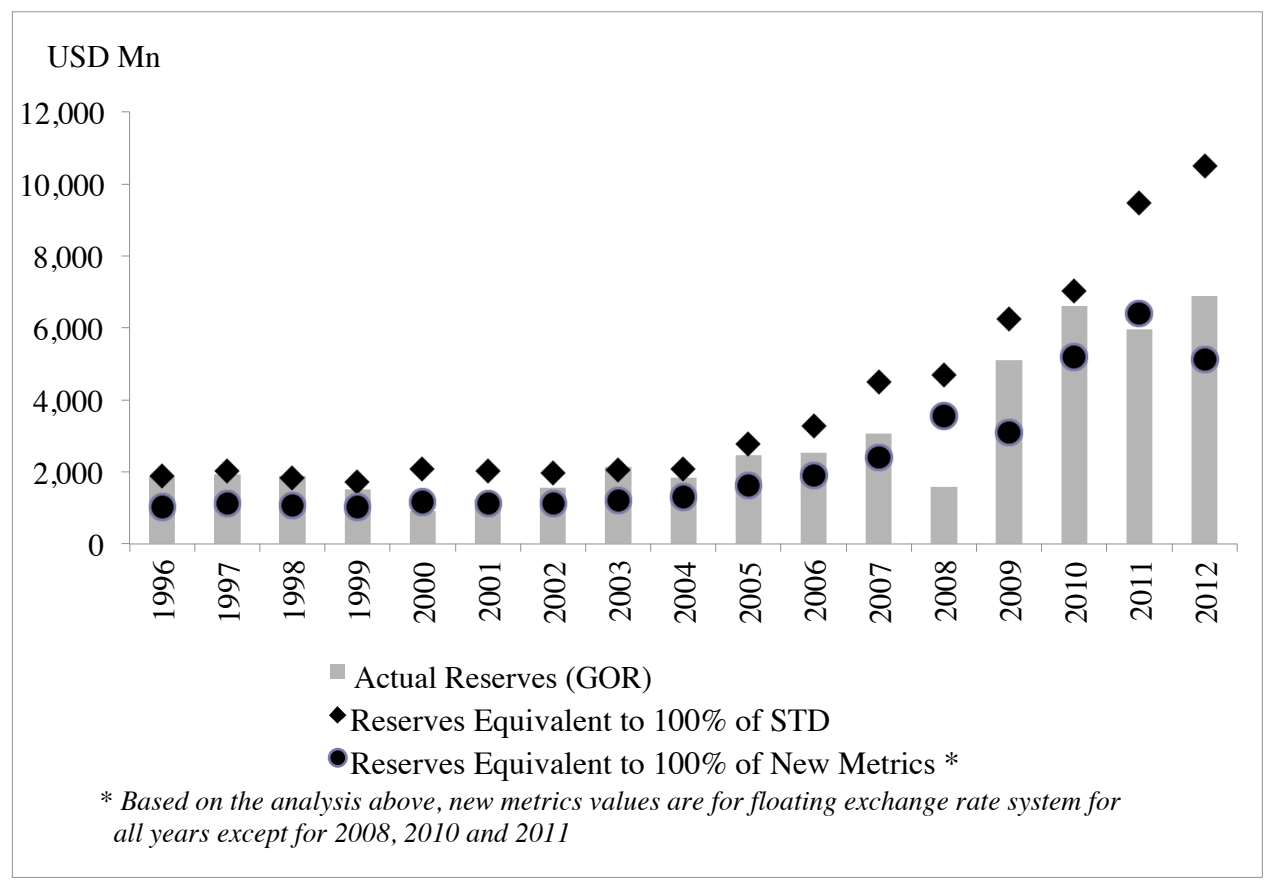

\section{Conclusions and Policy Implications}

International reserves are important financial resources for an economy as they have notable implications for the external and internal balance of an economy. At the same time, the quantity of reserve-holding can be simply interpreted as an indicator of economic strength. In this context, monetary authorities attempt to accumulate reserves mainly with a view of using them as a buffer in a crisis situation and strengthening the external sector through maintaining exchange rate stability. Similarly, the CBSL also pays increased attention on hoarding stocks of international reserves based on these key motives.

In this study, we have attempted to examine the reserve demand and adequacy in the Sri Lankan context. We find that in the period of investigation, Sri Lanka's long-run reserve policy appears to have been guided by import propensity, economic openness, short-term debt and liabilities and money supply. However, the reserve accumulation by 
the CBSL seems less sensitive to exchange rate volatility and the opportunity cost of holding reserves. In assessing reserve adequacy using the risk-weighted metrics developed by the IMF, we find that despite some variations during some turbulent periods, Sri Lanka has held adequate reserves and hence evidence for holding persistently excessive or inadequate levels of reserves is not found. Hence, the CBSL's focus on the reserve accumulation policy is justified.

However, caution should be exercised with regard to the reserve accumulation policy. While it is a sensible policy to accumulate reserves in order to withstand external stocks, it may be unwise to hoard reserves beyond a certain threshold. As excessive reserve accumulation leads to future consumption sacrifices, undue opportunity costs as well as monetary and quasi-fiscal costs, authorities may need to abstain from adopting a long-run 'excessive reserve accumulation' policy. At the same time, as the growth promoting mercantilist's view to accumulate large amounts of foreign reserves has been largely contests, prolonged reserve accumulation, which is aimed at exchange rate stabilisation and export promotion, may not be prudent as such policies entail several domestic macroeconomic risks.

From our analysis we observed that the opportunity cost of holding reserves was not significant to the model, implying Sri Lanka's reserve accumulation is less sensitive to the interest rate differential. Further, based on the reserve demand model, we noticed that it takes around 2 years to reach long-term equilibrium, indicating a slower response from the authorities when there were deviations from the desired level of reserves. Therefore, it may be argued that further emphasis should be placed on following more prudent and active reserve management practices by maintaining reserves to minimise opportunity cost and maximise returns, while adopting measures to build-up reserves to the desired levels, in the aftermath of a shock.

On the other hand, considering reserve adequacy in terms of the conventional metrics of "reserves to short term debt and liabilities", the international norm is to include both Treasury bills and bonds. However, $80 \%$ of the portfolio of foreign holdings of Treasury securities accounting for Treasury bonds with tenors of 1-20 years drives up the required level of reserves unnecessarily. This issue is addressed in the new risk-weighted metrics, where short term debt and liabilities is assigned a reasonable weight of $30 \%$ only. Therefore, it is advisable that we move away from using conventional metrics and adopt newly developed broader-based risk-weighted metrics.

Finally, we understand that our study is subject to several caveats and hence further research in this area is warranted. In particular, our observations are confined and limited to a static sample. As a further step to this research, it would warrant considering 
changes in the determinants over time, given the dynamic changes in the economic and financial structure of the economy. At the same time, it would be useful to have a more rigorous framework in which to characterise additional factors affecting the reserve demand in Sri Lanka and also to incorporate the interactions between the financial system and the process of reserve accumulation. We leave such untouched areas for the future research discourse.

It should be noted that risk weights computed by the IMF have been used without any modification in our study and we are aware about the limitation of using such common weights for the Sri Lankan context. However, as the first research in this area for the Sri Lankan context, we attempted to directly apply the weights provided by the IMF for emerging countries to Sri Lanka and as an initial step, it helps us to benchmark the Sri Lankan context against the IMF standards. Given the importance of considering country specific factors, we intend to extend our research after conducting necessary surveys to obtain the required weights applicable to Sri Lanka. 


\section{References}

Aizenman, J. and Marion N., 2003, “The High Demand for International Reserves in the

Far East: What is Going On?", Journal of the Japanese and International Economies, Vol. 17 (3), 370-400.

Aizenman, J., 2006, "International Reserves Management and the Current Account", NBER Working Paper Series, No. 12734, 1-52, National Bureau of Economic Research, Massachusetts.

Aizenman, J. and Lee J., 2007, "International Reserves: Precautionary vs. Mercantilist Views, Theory and Evidence”, Open Economies Review, Vol. 18 (2), 191-214.

Aizenman, J., Lee J. and Rhee Y., 2004. "International Reserves Management and Capital Mobility: Policy Considerations and a Case Study of Korea", NBER Working Paper Series, No. 10534, National Bureau of Economic Research, Massachusetts.

Aizenman, J. and Riera-Critchton D, 2006, "Real Exchange Rate and International Reserves in the Era of Growing Trade and Financial Integration", NBER Working Paper Series, No. 12363, 1-36, National Bureau of Economic Research, Massachusetts.

Badinger, H., 2004, “Austria's Demand for International Reserves and Monetary Disequilibrium: The Case of a Small Open Economy with a Fixed Exchange Rate Regime", Economica, Vol. 71 (281), 39-45.

Bahmani-Oskooee, M. and Brown, F., 2002, "Demand for International Reserves: A Review Article", Applied Economics, Vol. 34 (10), 1209-1226.

Barnichon, R., 2008, "International Reserves and Self-Insurance against External Shocks", IMF Working Paper, WP/08/149, International Monetary Fund, Washington DC.

Berg, A. and Pattillo C., 1999, "Are Currency Crises Predictable? A Test", IMF Staff Papers, Vol. 45, No. 2 (June), International Monetary Fund, Washington DC.

Bird, G. and Rajan R., 2003, "Too Much of a Good Thing? The Adequacy of International Reserves in the aftermath of Crises, World Economy, Vol. 26 (6), 873-891.

Cady, J. and Gonzalez-Garcia J., 2006, "The IMF Reserves Template and Nominal Exchange Rate Volatility”, IMF Working Paper, No. 627, 1-24, International Monetary Fund, Washington DC.

Calvo, G. A. and Mendoza E. G., 1996, “Mexico's Balance-of-Payments Crisis: A Chronicle of A Death Foretold", Journal of International Economics, Vol. 41 (3-4), 235-264. 
Central Bank of Sri Lanka, 1998, "Economic Progress of Independent Sri Lanka", Colombo.

Central Bank of Sri Lanka, “Annual Report”, Various Issues, Colombo.

Chan, S. S., 2007, “The Basic Framework for International Reserves and Its Application to Macao", Working Papers of Research and Statistics Department, Monetary Authority of Macao.

Cheung, Y. and Ito H., 2009, “A Cross-Country Empirical Analysis of International Reserves”, International Economic Journal, Vol. 23 (4), 447-481.

Cheung, Y. and Qian, X., 2009, "Hoarding of International Reserves: Mrs Machlup's Wardrobe and the Joneses", Review of International Economics, Vol. 17 (4), 824-843.

Cruz, M. and Kriesler P., 2008, "International Reserves, Growth and Effective Demand", School of Economics Discussion Paper, 2008/16, the University of New South Wales, Sydney.

Cruz, M. and Walters B., 2008, "Is the Accumulation of International Reserves Good for Development?”, Cambridge Journal of Economics, Vol. 32 (5), 665-681.

Dehesa, M., Pineda E. and Samuel W., 2009, “Optimal Reserves in the Eastern Caribbean Currency Union”, IMF Working Paper, WP/09/77, International Monetary Fund, Washington DC.

Dominguez, K. M. E., Hashimoto, Y. and Ito, T., 2012, "International Reserves and the Global Financial Crisis”, Journal of International Economics, Vol. 88 (2), 388-406.

Dooley, M., Garber P., and Folkerts-Landau D., 2003, “An Essay on the Revived Bretton Woods System”, NBER Working Paper Series, No. 9971, National Bureau of Economic Research, Massachusetts.

Drummond, P. and Dhasmana A., 2008, "Foreign Reserve Adequacy in Sub-Saharan Africa", IMF Working Paper, WP/08/150, International Monetary Fund, Washington DC.

Edison, H., 2003, “Are Foreign Reserves in Asia too High?”, World Economic Outlook, 2003 Update, International Monetary Fund, Washington, DC.

Elhiraika, A. and Ndikumana L., 2007, "Reserves Accumulation in African Countries: Sources, Motivations, and Effects", Working Paper 2007-12, Conference Papers of African Economic Conference: Opportunities and Challenges for Africa in the Global Arena, AFDB and ECA, November 15-17, Addis Ababa, Ethiopia. 
Engle, R. F. and Granger C. W. J., 1987, "Cointegration and Error Correction: Representation, Estimation and Testing”, Econometrica, Vol. 55 (2), 251-276.

Fischer, S., 2001, “Opening Remarks”, IMF/World Bank International Reserves: Policy Issues Forum, April 28, Washington DC.

Frenkel, R. and Ros J., 2006, "Unemployment and the Real Exchange Rate in Latin America”, World Development, Vol. 34 (4), 631-46.

García, P. and Soto C., 2004, "Large Hoardings of Reserves: Are They Worth It?", Working Paper, No. 299, December, Central Bank of Chile.

Gosselin, M. and Parent N., 2005, “An Empirical Analysis of Foreign Exchange Reserves in Emerging Asia”, Bank of Canada Working Paper, 2005-38, Ontario.

Green, R. and Torgerson T., 2007, “Are High Foreign Exchange Reserves in Emerging Markets a Blessing or a Burden?", Department of the Treasury: Office of International Affairs Occasional Paper, No. 6, Washington DC.

Hauner, D., 2006, “A Fiscal Price Tag for International Reserves”, International Finance, Vol. 9 (2), 169-195.

Huang, G., 1995, “Modelling China's Demand for International Reserves”, Applied Financial Economics, Vol. 5 (5), 357-366.

International Monetary Fund, 2011, “Assessing Reserve Adequacy”, (Prepared by the Monetary and Capital Markets, Research, and Strategy, Policy, and Review Departments in consultation with other Department) February.

International Monetary Fund, 2000, "Debt and Reserve-Related Indicators of External Vulnerability", (Prepared by the Policy Development and Review Department in consultation with other Department) March.

International Monetary Fund, 2003, “Are Foreign Exchange Reserves in Asia too High?”, Chapter II, World Economic Outlook, September 2003: 78-92.

International Monetary Fund, 1993, "Balance of Payments Manual”, Washington DC.

International Monetary Fund, 1996-2012, “Annual Report on Exchange Arrangements and Exchange Restrictions (AREAER)", Washington DC.

Jeanne, O., 2007, "International Reserves in Emerging Market Countries: Too Much of a Good Thing?", IMF Research Department Papers, International Monetary Fund, Washington DC. 
Jeanne, O. and Rancière R., 2006, "The Optimal Level of International Reserves for Emerging Market Countries: Formulas and Applications", IMF Working Paper, WP/06/229, International Monetary Fund, Washington DC.

Johansen, S., 1988. Statistical Analysis of Cointegration Vectors. Journal of Economic Dynamics and Control, Vol. 12 (2-3), 231-254.

Johansen, S. and Juselius, K., 1990, "Maximum Likelihood Estimation and Inference on Cointegration - with Applications to the Demand for Money", Oxford Bulletin of Economics and Statistics, Vol. 52 (2), 169-210.

Lane, P. R. and Burke D., 2001, "The Empirics of Foreign Reserves", Open Economies Review, Vol. 12 (4), 423-434.

Li, J., Sula O. and Willett T. D., 2008, "Exchange Rate Regimes and Optimal Reserve Holdings in a World of Capital Account Crises",

Lloyd-Ellis, H. and Nechi S., 2008, "Foreign Reserves Accumulation in Emerging Economies: Determinants and Sustainability Case of Mexico", Working Papers of Department of Economics, Queen's University, Ontario.

Mendoza, R. U., 2004, "International Reserve Holding in the Developing World: Self Insurance in a Crisis-prone Era?”, Emerging Markets Review, Vol. 5 (1), 61-82.

Mohanty, M. and Turner P., 2006, "Foreign Exchange Reserve Accumulation in Emerging Markets: What are the Domestic Implications?", BIS Quarterly Review, September, 39-52, Bank of International Settlements, Basle.

Neely, C. J., 2000, “Are Changes in Foreign Exchange Reserves Well Correlated with Official Intervention?", Review : September - October 2000, Federal Reserve Bank of St. Louis.

Noyer, C., 2007, "Foreign Reserve Accumulation: Some Systemic Implications", Papers of Salzburg Global Seminar, October, 1, Banque de France.

Ozyildirim, S. and Yaman, B., 2005, "Optimal versus Adequate Level of International Reserves: Evidence for Turkey”, Applied Economics, Vol. 37 (13), 1557-1569.

Özdemir, K. A., 2004, “Optimal International Reserves Behavior for Turkey”, Research Department Working Paper, No. 04/10, Central Bank of the Republic of Turkey.

Park, D. and Estrada G. B., 2009, “Are Developing Asia's Foreign Exchange Reserves Excessive? An Empirical Examination", ADB Economics Working Paper Series No. 170, August, Asian Development Bank, Manila. 
Prabheesh, K. P., Malathy D. and Madhumathi R., 2007, "Demand for Foreign Exchange Reserves in India: A Co-integration Approach", South Asian Journal of Management, Vol. 14 (2), 36-46.

Romero, A. M., 2005, "Comparative Study: Factors that Affect Foreign Currency Reserves in China and India", The Park Place Economist, Volume XIII, 79-88.

Ruiz-Arranz, M. and Milan Z., 2008, “Are Emerging Asia's Reserves Really Too High?”, IMF Working Paper, WP/08/192, International Monetary Fund, Washington DC.

Schiller, T., 2007, “How Asia Could Have Vibrant Capital Markets?", Financial Times, April 25.

Sehgal, S. and Sharma C., 2008, "A Study of Adequacy, Cost and Determinants of International Reserves in India", International Research Journal of Finance and Economics, Issue 20, 75-90.

Shcherbakov, S. G., 2002, "Foreign Reserve Adequacy: Case of Russia”, Conference Paper of Fifteenth Meeting of the IMF Committee on Balance of Payments Statistics, Australia.

Tereanu, T., 2010, "International Reserve Adequacy in the Gambia", IMF Working Paper, WP/10/215, International Monetary Fund, Washington DC.

Weymark, D., 1995, "Estimating Exchange Market Pressure and the Degree of Exchange Market Intervention for Canada," Journal of International Economics, Vol. 39 (3-4), 273-295.

Wijnholds, J. O. de B. and Kapteyn A., 2001, "Reserve Adequacy in Emerging Market Economies", IMF Working Paper, WP/01/143, International Monetary Fund, Washington DC. 


\section{Appendix 1}

\section{Reserve Adequacy (Conventional Benchmarks)}

Figure A1.1

\section{Gross Official Reserves to Months of Imports}

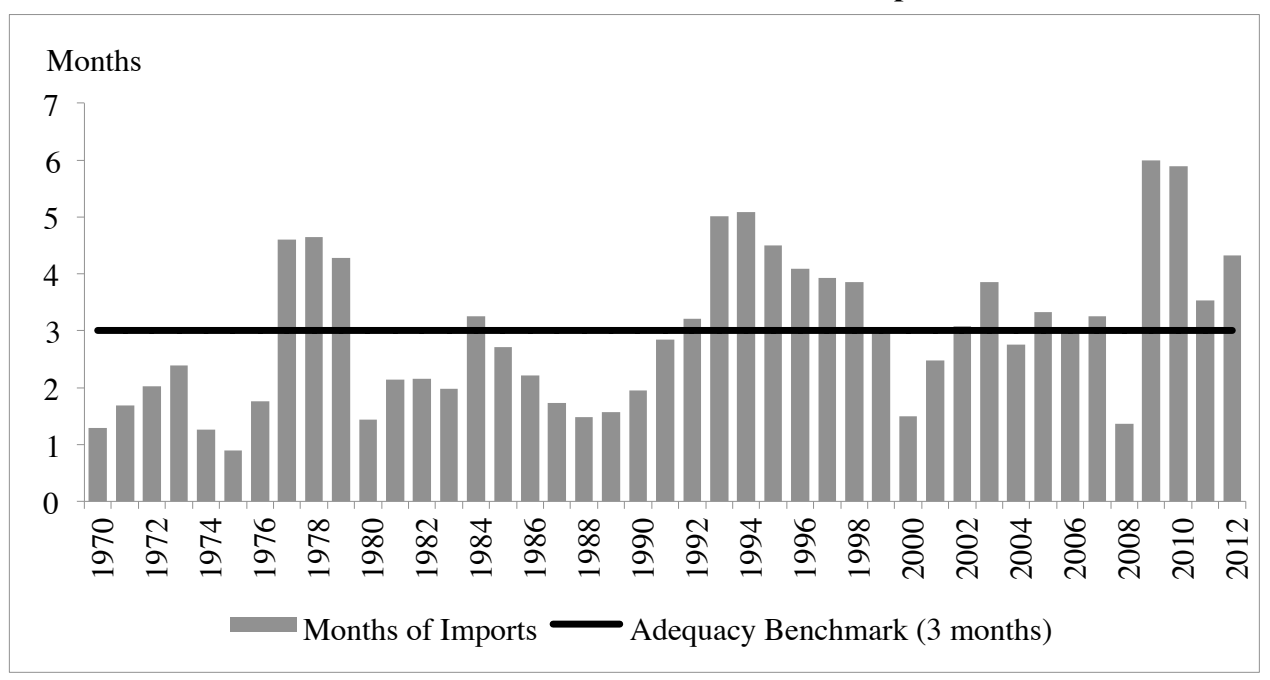

Figure A1.2

Gross Official Reserves to Short-term Debt and Liability

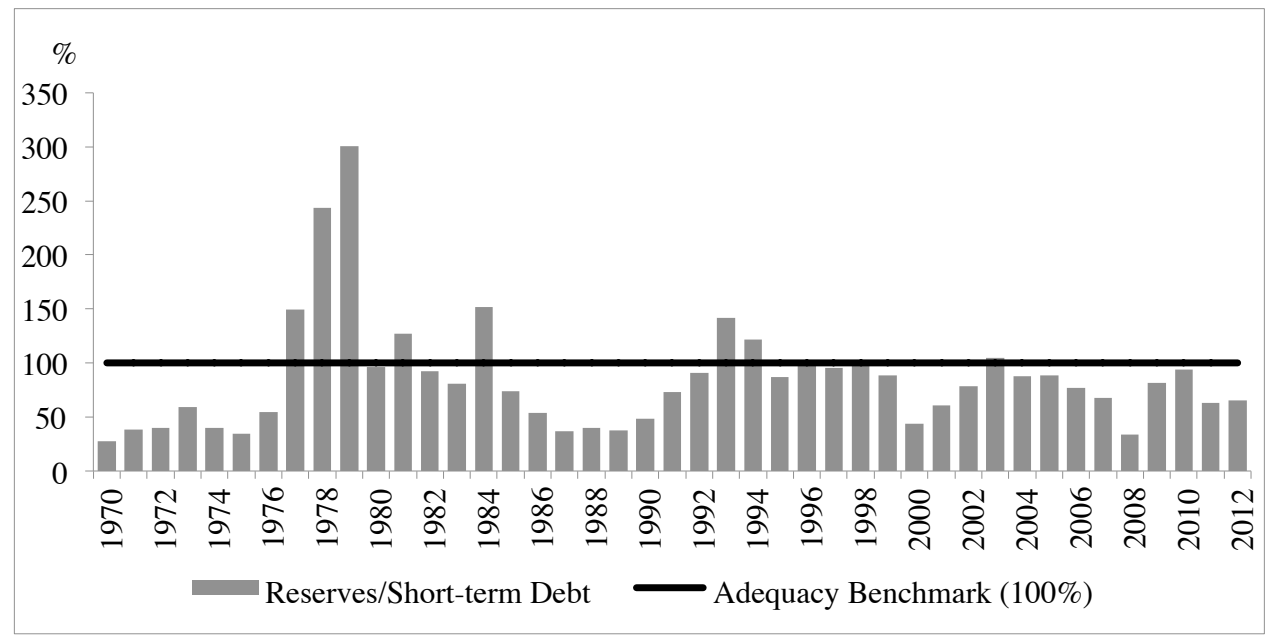


Figure A1.3

\section{Gross Official Reserves to Broad Money}

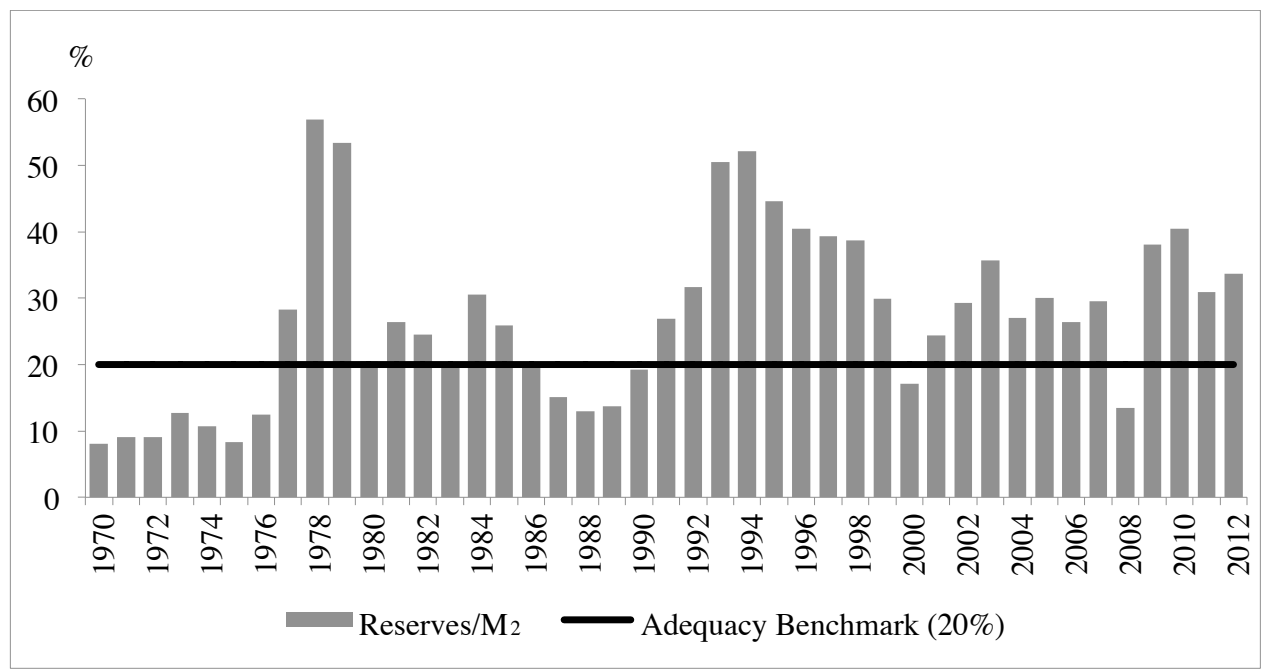

Figure A1.4

\section{Gross Official Reserves to GDP}

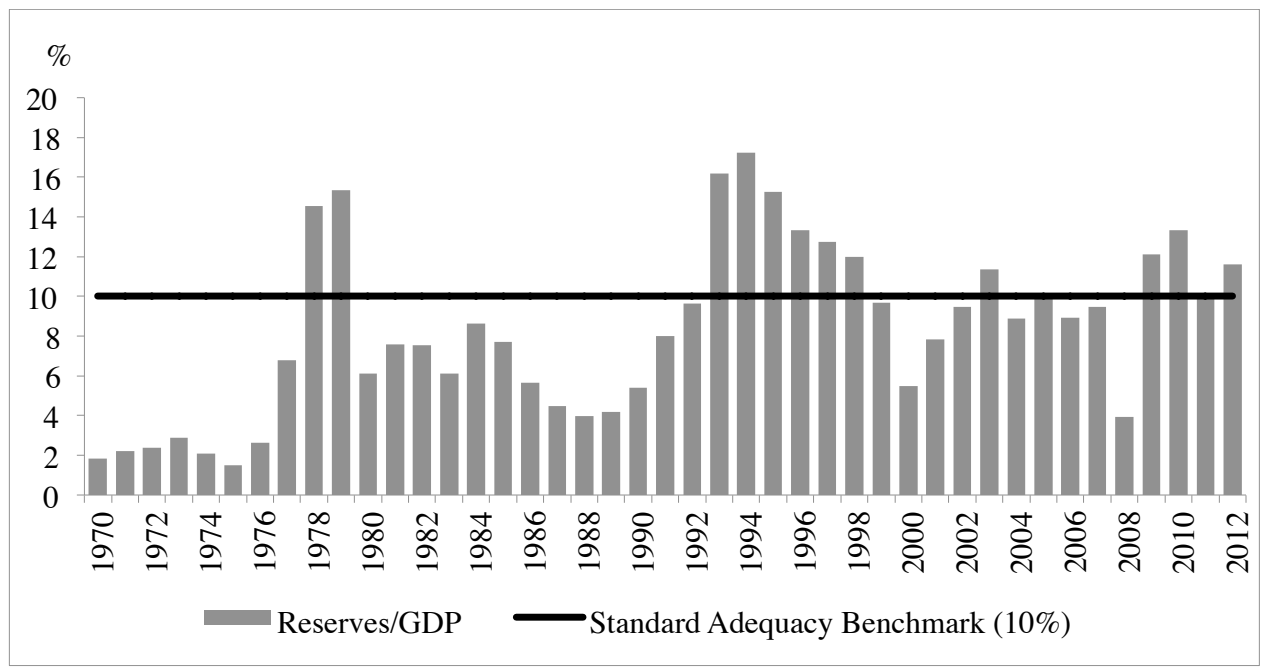


Appendix 2

\section{Reserve Demand Model - Movements in Model Variables}

Figure A2.1

\section{Movements in Empirical Model Variables}
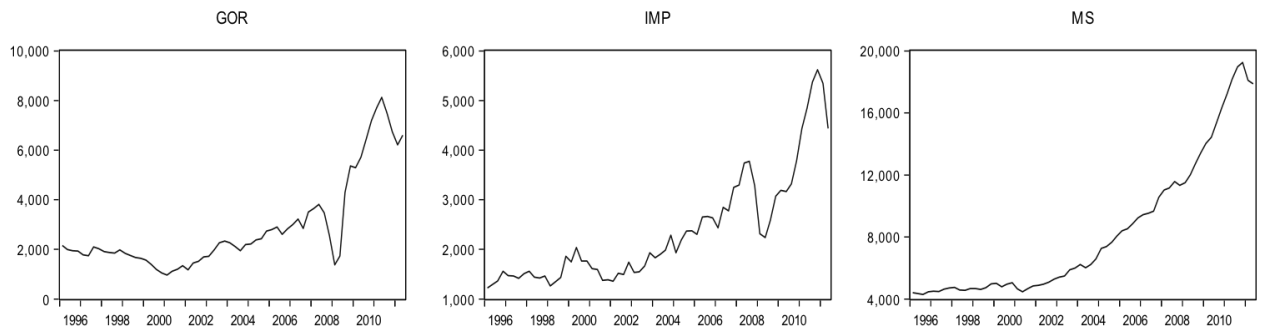

STD

OPEN
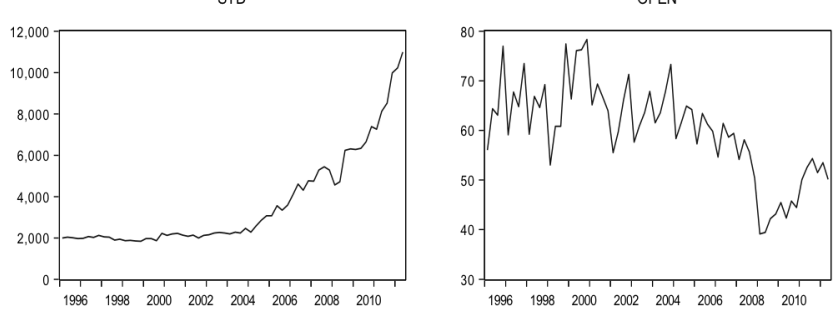

OPCOST

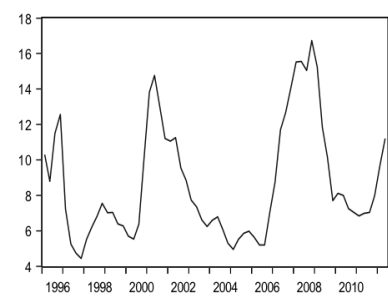

XVOL

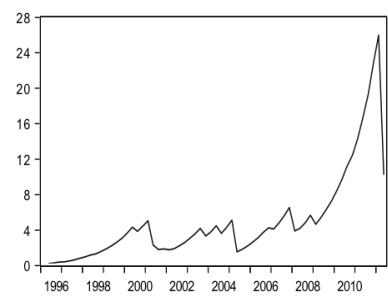

Note: Variable names are as given in Table 4. 